\title{
Avaliação comparativa "in vitro" da capacidade seladora à infiltração bacteriana dos cimentos MTA branco, cinza e Sealapex consistente em obturações retrógradas.
}

\section{AMÉLIO BORGES TAVEIRA}

Dissertação apresentada à Faculdade de Odontologia de Bauru da Universidade de São Paulo, como parte dos requisitos para obtenção do grau de Mestre em Odontologia, área de Endodontia.

(Edição Revisada)

\section{BAURU}




\section{Avaliação comparativa "in vitro" da capacidade seladora à infiltração bacteriana dos cimentos MTA branco, cinza e Sealapex consistente em obturações retrógradas.}

\section{AMÉLIO BORGES TAVEIRA}

Dissertação apresentada à Faculdade de Odontologia de Bauru da Universidade de São Paulo, como parte dos requisitos para obtenção do grau de Mestre em Odontologia, área de Endodontia.

(Edição Revisada)

Orientador: Prof. Dr. Roberto Brandão Garcia

\section{BAURU}




\section{Taveira, Amélio Borges}

T198a Avaliação comparativa “in vitro" da capacidade seladora à infiltração bacteriana dos cimentos MTA branco, cinza e Sealapex consistente em obturações retrógradas. / Amélio Borges Taveira - Bauru, 2005.

xv , ....p.100: il.; 30cm.

Dissertação (Mestrado) -- Faculdade de Odontologia de Bauru. Universidade de São Paulo.

Orientador: Prof. Dr. Roberto Brandão Garcia.

Autorizo, exclusivamente para fins acadêmicos e científicos, a reprodução total ou parcial desta dissertação/tese, por processos fotocopiadores e outros meios eletrônicos.

Assinatura:

Bauru, 27 de junho de 2005.

Aprovado pelo Comitê de Ética em Pesquisa da Faculdade de Odontologia de BauruUSP.

Protocolo: $163 / 2004$.

Data: 30 de novembro de 2004. 


\section{DADOS CURRICULARES}

\section{AMÉLIO BORGES TAVEIRA}

Nascimento

Filiação

1995- 1998

$2003-2005$

Associações
02 de maio de 1974

Uberlândia - MG.

Antônio Carlos de Assis Taveira

Vera Consuelo Borges Taveira

Curso de Graduação em Odontologia, Faculdade Odontologia de Ribeirão Preto Universidade de São Paulo.

Curso de Pós-graduação em Endodontia, Nível de Mestrado, Faculdade de Odontologia Universidade de São Paulo.

SBPqO - Sociedade Brasileira de Pesquisas Odontológicas. 


\section{Dedicatória}

Ao meu amado pai Antônio Carlos pelo amor e dedicação que sempre dedicou aos filhos mesmo no momento de maior dor de sua vida. Pai, mesmo hoje, já tendo me tornado homem saiba que o senhor ainda é o meu "porto seguro" e minha referência nos momentos de dúvida. EU TE AMO.

À memória de minha mãe VERA que mesmo tendo ficado tão pouco tempo em nosso convívio, sei que sempre esteve presente em minha vida.

À minha avó Eliza que substitui a filha na dura obrigação de ajudar a criar quatro crianças, mas que o fez com muito amor.

Obrigado vózinha.

À Cristiane, Carla e Maria Elisa minhas adoradas irmãs que me enchem de amor e carinho, sem vocês minha vida teria sido muito solitária.

À minha amada MELIZA, pelo carinho, amor, pelo constante estímulo e paciência nas horas difíceis dessa caminhada, você é muito mais que minha noiva, você é a minha companheira. 


\section{AGRADEÇO ESPECIALMENTE}

Ao meu orientador Roberto Brandão Garcia pelos valiosos ensinamentos, dedicação e atenção e pela forma cordial com que me recebeu. Ao senhor toda minha amizade e respeito.

Ao Prof. Dr. Sérgio Aparecido Torres por ter me ajudado no momento que mais precisei de auxílio e orientação durante meu curso de mestrado. $\mathrm{O}$ seu respeito ao aluno $\mathrm{e}$ desprendimento sempre serão um exemplo para mim.

MEV MUITO OBRIGADO 
As minhas amigas Luzinha e Rê Falchete sem vocês minha vida em Bauru teria sido quase insuportável, saibam que minha conquista também é de vocês.

À Danieli e Danilo que me acolheram em Bauru, grandes amigos e futuros padrinhos. FURKIS obrigado pelo apoio, amizade e companheirismo. Vocês realmente entendem 0 significado do conceito de amizade.

Vocês são muito importantes na minha vida 


\section{AGRADECIMENTOS INSTITUCIONAIS}

À Direção da Faculdade de Odontologia de Bauru, Universidade de São Paulo, na pessoa da Diretora, Professora Doutora Maria Fidela de Lima Navarro.

À Comissão de Pós-Graduação da Faculdade de Odontologia de Bauru, Universidade de São Paulo na pessoa do Presidente, Professor Doutor José Carlos Pereira.

Ao coordenador do curso de Pós-Graduação em Endodontia, Professor Doutor Clóvis Monteiro Bramante.

A CAPES, pelo auxílio financeiro. 


\section{AGRADECIMENTOS}

Aos Professores Clóvis Monteiro Bramante, Ivaldo Gomes de Moraes e Norberti Bernardineli, agradeço pela oportunidade de realizar o meu mestrado e pela atenção a mim dedicada.

Ao Professor Doutor Luis Antônio de Assis Taveira por toda a ajuda desde que cheguei em Bauru.

A todos os Professores do curso de pósgraduação, da Faculdade de Odontologia de Bauru, USP meus sinceros agradecimentos.

À pós-graduanda e minha querida amiga Danieli Colaço Ribeiro Siqueira, pelo auxílio na fase experimental deste trabalho e pelas inúmeras correções realizadas. Dani obrigado por sempre discordar de mim, mas sem nunca se irritar comigo.

A todos os funcionários da Biblioteca da FOB USP, pela ajuda, atenção e amizade.

A todos os amigos e colegas da pósgraduação, com quem aprendi muito. 
A dona Ana e seu João que abriram as portas de sua casa

A todos que direta ou indiretamente, colaboraram para a realização deste trabalho. 


\section{SUMÁRIO}

LISTA DE FIGURAS Xii

LISTA DE ABREVIATURAS Xiii

RESUMO XIV X X

1 INTRODUÇÃO 1

2 REVISÃO DE LITERATURA

2.1 Agregado de Trióxido Mineral - MTA 6

$\begin{array}{ll}2.2 \text { Sealapex } & 26\end{array}$

3 PROPOSIÇÃO

4 MATERIAL E MÉTODOS 43

$\begin{array}{ll}\text { 4.1 MATERIAL } & 44\end{array}$

$\begin{array}{ll}\text { 4.1.1 Dentes } & 44\end{array}$

4.1.2 Cimentos utilizados 44

4.1.2.1 Cimento MTA Angelus cinza e branco 44

4.1.2.2 Sealapex Consistente 46

$\begin{array}{ll}\text { 4.1.2.3 Sealapex } & 46\end{array}$

4.1.2.4 Óxido de Zinco $\quad 47$

4.1.3 Aparato experimental 48

4.1.3.1 Tubo de microcentrífuga 48

$\begin{array}{ll}\text { 4.1.3.2 Vidro tipo penicilina } & 48\end{array}$ 
4.2 MÉTODOS 50

4.2.1 Preparo dos dentes $\quad 50$

4.2.2 Preparo dos grupos experimentais 51

4.2.3 Preparo do aparato $\quad 53$

4.2.4 Preparo do inóculo $\quad 55$

4.2.5 Obtenção dos resultados 56

5 RESULTADOS 59

6 DISCUSSÃO 64

6.1 Discussão da metodologia 66

6.1.1 Técnica de infiltração 66

6.1.2 Escolha do material retrobturador 68

6.1.3 Aparato experimental 70

6.2 Discussão dos resultados 72

6.3 Considerações finais $\quad 73$

7 CONCLUSÕES

$\begin{array}{ll}\text { ANEXO } & 77\end{array}$

REFERÊNCIAS BIBLIOGRÁFICAS 81

$\begin{array}{ll}\text { ABSTRACT } & 97\end{array}$

$\begin{array}{ll}\text { APÊNDICE } & 100\end{array}$ 


\section{LISTA DE FIGURAS}

FIGURA 1 - Cimento MTA Angelus cinza

FIGURA 2 - Cimento MTA Angelus Branco

FIGURA 3 - Cimento Sealapex

FIGURA 4 - Cimento de Óxido de Zinco

FIGURA 5 - Tubo de microcentrífuga

FIGURA 6 - Vidro tipo penicilina

FIGURA 7 - Raízes retrobturadas

FIGURA 8 - Esquema da montagem da raiz dental no tubo de microcentrífuga

FIGURA 9 - Câmera de fluxo laminar

FIGURA 10 - Esquema do aparato experimental

FIGURA 11- Esquema do aparato após a inoculação do Enterococcus faecalis

FIGURA 12 - Aparatos com e sem turvação 


\section{LISTA DE ABREVIATURAS E SÍMBOLOS}

$\begin{array}{ll}\% & \text { Porcentagem } \\ n^{\circ} . & \text { Número } \\ \text { MTA } & \text { Agregado de Trióxido Mineral } \\ \text { EBA } & \text { Ácido Etoxi Benzóico } \\ \text { IRM } & \text { Material restaurador intermediário } \\ \text { Ltda. } & \text { Limitada } \\ \text { pH } & \text { Potencial hidrogeniônico } \\ \text { FOB } & \text { Faculdade de Odontologia de Bauru } \\ \text { USP } & \text { Universidade de São Paulo } \\ \text { p } & \text { Significância estatística } \\ \text { ATCC } & \text { American Type Culture Collection } \\ \text { PCR } & \text { Reação de cadeia polimerase }\end{array}$




\section{RESUMO}

Os cimentos MTA Angelus cinza, MTA Angelus branco e Sealapex acrescido de óxido de zinco (Sealapex consistente) foram avaliados quanto à sua capacidade seladora frente à infiltração bacteriana. Foram utilizados 80 dentes humanos uniradiculares extraídos, todos os dentes tiveram suas coroas removidas logo abaixo da junção cemento-esmalte e foram instrumentados até que uma lima tipo Kerr n. ${ }^{\circ} 40$ atingisse o comprimento de trabalho. As raízes foram divididas aleatoriamente em três grupos experimentais de 20 espécimes, um para cada cimento, e em dois grupos controles de 10 espécimes cada. As raízes foram apicectomizadas com um ângulo de $90^{\circ}$ em relação ao longo eixo e foram confeccionadas retrocavidades de três milímetros de profundidade, as retrocavidades foram preenchidas com os cimentos $e$ a superfície externa de todas as raízes foi impermeabilizada com Araldite com exceção da superfície apicectomizada. As raízes foram inseridas em tubos de microcentrífuga e fixadas com Araldite. O conjunto (raiz dental e tubo de microcentrífuga) foi esterilizado em óxido de etileno, e após a esterilização, foi montado em frascos tipo penicilina, contendo cinco mililitros de caldo BHI esterilizado. Após esse procedimento, depositamos $400 \mu \mathrm{L}$ da cultura de Enterococcus faecalis ATCC 29212 no interior do tubo de microcentrífuga. O aparato (raiz, tubo de microcentrífuga, vidro e bactéria) foi mantido em estufa a $37^{\circ} \mathrm{C}$, durante 120 dias para verificação da turvação do meio de cultura, indicativa de infiltração bacteriana, esse monitoramento foi realizado diariamente. Durante este período ocorreram infiltrações em 11 espécimes do grupo do MTA cinza, em 10 do Sealapex consistente e 9 espécimes do MTA branco. Aplicando o teste de Qui-Quadrado aos resultados obtidos, concluiu-se 
que os cimentos testados comportaram-se de maneira semelhante frente à infiltração bacteriana durante o período experimental testado. 


\section{INTRODUÇÃO}

Até o final do século XIX não se sabia da participação dos microrganismos no desenvolvimento e perpetuação de pulpites e periodontites apicais, somente em 1894, MILLER ${ }^{58}$ descreveu a presença de bactérias no interior do canal radicular após examinar esfregaços obtidos de canais radiculares com polpas necróticas. Anos mais tarde, KAKEHASHI; STANLEY; FITTZGERALD ${ }^{44}$ (1965) e MÖLLER 59 (1981) confirmaram que bactérias são os principais agentes etiológicos da inflamação pulpar, necrose e da lesão periapical, cuja persistência no sistema de canais radiculares pode levar à reabsorção da raiz dental e do osso alveolar.

O tratamento endodôntico tem como objetivo a antisepsia do sistema de canais radiculares, alcançada com a remoção destas bactérias e de restos necróticos e a total obturação do canal radicular. Porém, devido à complexa anatomia do sistema de canais radiculares ou a problemas iatrogênicos muitas vezes aqueles objetivos não são atingidos de forma adequada, propiciando a persistência da lesão radicular.

Nesses casos o retratamento via convencional é o indicado e usualmente, se bem realizado, resulta em sucesso. Contudo, quando o tratamento convencional mostra-se insuficiente ou é contra-indicado, a cirurgia parendodôntica está indicada. Dentre as diversas modalidades cirúrgicas parendodônticas existentes a obturação retrógrada é uma das mais empregadas e consiste na exposição parcial da raiz do dente envolvido, ressecção da porção apical, preparo de uma cavidade e seu preenchimento com o material retrobturador. 
Segundo BERNABÉ; HOLLAND ${ }^{13}$ (2004), o material retrobturador deve promover o selamento apical impedindo a infiltração de bactérias provenientes do interior do canal radicular para os tecidos periapicais bem como de líquido intersticial para o canal radicular, além de possuir excelente capacidade seladora esse material deve ser biologicamente compatível, caso contrário, a despeito de sua capacidade seladora, poderá gerar uma série de eventos patológicos desfavoráveis, que poderão levar ao insucesso do tratamento.

Inúmeros materiais têm sido empregados como retrobturadores, desde materiais utilizados em restaurações dentais como o amálgama, resina composta e ionômero de vidro como também materiais específicos para o tratamento endodôntico, como os cimentos endodônticos, guta-percha e mais recentemente o MTA.

Dentre os cimentos endodônticos, o Sealapex é um cimento que se destaca devido às suas excelentes propriedades biológicas (BERNABÉ; HOLLAND ${ }^{13}$ (2004), HOLLAND; SOUZA $^{40}$ (1985), LUIZ ${ }^{52}(2003)$, SILVA (1995) $\left.{ }^{69}\right)$, podendo ser utilizado em íntimo contato com os tecidos periapicais. Apresenta-se na forma de pasta-pasta, porém, para sua utilização como material retrobturador deve-se acrescentar óxido de zinco, até que o cimento fique com a consistência de "massa de vidraceiro", e passa a ser denominado de Sealapex consistente BERNABÉ; HOLLAND ${ }^{13}$ (2004), LUIZ ${ }^{52}$ (2003).

A despeito de suas boas propriedades biológicas o Sealapex pode apresentar alguns inconvenientes quando utilizado como material retrobturador. Segundo SILVA ${ }^{69}$ (1995), esse cimento possui grande solubilidade. Resultados semelhantes foram obtidos por VALERA ${ }^{91}$ (1995), TAGGER; TAGGER; KFIR ${ }^{77}$ (1988) e SCHÄFER; ZANDBIGLARI ${ }^{67}$ (2003) que relataram a solubilização desse cimento bem como sua 
capacidade de desintegração. Este fato possui enorme relevância clínica, pois a solubilidade é uma propriedade inconveniente para os materiais retrobturadores, e apesar de já existirem trabalhos que demonstrem o excelente comportamento biológico do Sealapex consistente (BERNABÉ; HOLLAND ${ }^{\mathbf{1 3}}$ (2004), LUIZ $\mathbf{L}^{52}(2003)$ ) sua capacidade seladora ainda não foi estudada. Outro material que tem sido amplamente utilizado para esse fim é o Agregado de Trióxido Mineral (Mineral Trioxide Aggregate - MTA), desenvolvido por Torabinejad, e que apresenta excelentes propriedades mecânicas e biológicas, porém o seu elevado custo ainda é um empecilho para sua utilização rotineira em países como o Brasil.

No ano de 2001, a empresa brasileira Angelus desenvolveu um MTA nacional de custo inferior e aparentemente similar ao MTA Pro Root (ARAúJO(2004) ${ }^{7}, \operatorname{MENEZES(2004)~}{ }^{56}$, ROCHA(2003) ${ }^{65}$, SILVA NETO(2003) ${ }^{70,} \operatorname{SIQUEIRA}(2004)^{72}$, porém ainda existem poucos estudos sobre suas propriedades. Recentemente no ano de 2004, a empresa Angelus lançou o MTA branco sobre o qual ainda não existem trabalhos publicados referentes às suas propriedades seladoras frente à infiltração bacteriana.

Diante disso é conveniente realizarmos um estudo para avaliarmos a capacidade seladora dos cimentos MTA cinza e MTA branco e do Sealapex consistente frente à infiltração bacteriana. 


\section{REVISÃO DE LITERATURA}

A revisão de literatura será apresentada em duas partes referentes aos materiais estudados.

\section{1 - Agregado de Trióxido Mineral (MTA)}

A capacidade do MTA, amálgama e IRM em selar perfurações radiculares foi avaliada comparativamente por LEE; MONSEF; TORABINEJAD ${ }^{48}$, em 1993, em 50 molares humanos extraídos. Foram realizadas perfurações nas raízes mesiais, as perfurações foram ampliadas até que a ponta de uma lima tipo Kerr $\mathrm{n}^{\circ}$. 80 a ultrapassasse em cinco milímetros. Os dentes foram colocados em solução salina para simular as condições clínicas, e divididos em quatro grupos: 1) Dentes com as perfurações seladas com amálgama, 2) Dentes com perfurações seladas com IRM, 3) Dentes com perfurações seladas com MTA e 4) Dentes com perfurações não seladas e utilizados como controle. Os dentes foram mantidos por quatro semanas em solução salina e depois imersos por 48 horas em azul de metileno. Os resultados mostraram que o grupo do MTA apresentou menos infiltração quando comparado aos outros materiais testados e menor tendência ao extravasamento.

A capacidade seladora apical do MTA, amálgama e do Super-EBA foi avaliada TORABINEJAD; WATSON; PITT FORD $^{81}$, em 1993. Utilizaram 30 dentes humanos uniradiculares extraídos, os quais foram instrumentados e obturados com gutapercha e cimento endodôntico, apicectomizados numa extensão de três a quatro milímetros com um ângulo de $90^{\circ}$ em relação ao 
longo eixo da raiz e foram confeccionadas retrocavidades de três milímetros de profundidade que foram preenchidas com os cimentos testados e a superfície externa de todos os dentes foi impermeabilizada com esmalte de unha. Todos os dentes permaneceram por 24 horas em corante (Rhodamine B), posteriormente foram seccionados longitudinalmente e analisados quanto à extensão da infiltração do corante. Os resultados demonstraram que o grupo do MTA apresentou os menores valores de infiltração do corante.

TORABINEJAD et al. ${ }^{82}$, em 1994, utilizando 90 dentes uniradiculares avaliaram a capacidade seladora do MTA, amálgama, IRM e super-EBA quando utilizados em retrobturações contaminadas ou não com sangue. Os dentes tiveram suas coroas removidas, foram instrumentados e posteriormente obturados com guta-percha e cimento endodôntico, após a obturação, realizou-se a apicectomia e confecção de retrocavidades de dois milímetros as quais foram preenchidas com os materiais experimentais. Metade das raízes foi seca antes da inserção do material retrobturador, e a outra metade foi contaminada com sangue antes da inserção do material. Todas as raízes foram colocadas em solução de azul de metileno a $1 \%$ por 72 horas e posteriormente medida a extensão de infiltração do corante. A presença ou ausência de sangue não teve efeito significante na extensão de infiltração do corante em nenhum grupo testado. Entretanto, os resultados demonstraram que o MTA obteve menos infiltração do que os outros materiais testados, com ou sem contaminação por sangue.

A capacidade seladora frente a corantes de alguns materiais utilizados em retrobturações também foi avaliada por 
BATES; DAVID; DEL RIO ${ }^{11}$, em 1996, os autores utilizaram-se de 76 dentes humanos extraídos, dos quais removeram as coroas na junção cemento-esmalte e os instrumentaram com limas Flex-R e brocas Gates-Glidden. Todas as raízes tiveram os três milímetros apicais removidos perpendiculares ao seu longo eixo. Na sequência todas as raízes foram impermeabilizadas e tiveram retrocavidades de três milímetros de profundidade preparadas com ultra-som. Os espécimes foram divididos em três grupos experimentais e retrobturados com amálgama, MTA ou Super-EBA logo em seguida a realização das retrobturações. As raízes ficaram em solução salina por 24 horas, após esse período, foram montadas em um aparato desenvolvido para testar a infiltração de corantes. A infiltração foi avaliada nos seguintes períodos experimentais: 24 horas, 72 horas, duas semanas, quatro semanas, oito semanas e 12 semanas utilizando-se o aparato de "filtração de fluído". A infiltração nos grupos do MTA e do Super-EBA foi estatisticamente menor que no grupo do amálgama nos períodos de 24 horas, 72 horas e 2 semanas, nos demais períodos não houve diferença estatística entre os três materiais.

AQRABAWI $^{2}$, em 2000, avaliou a capacidade do amálgama, Super-EBA e MTA em impedir a infiltração de corante via apical em 79 dentes humanos extraídos. Realizou-se a instrumentação, a apicectomia e confecção de uma retrocavidade com três milímetros de profundidade, os dentes foram divididos aleatoriamente em três grupos para a realização da obturação retrógrada com os materiais experimentais. A eficácia do selamento apical foi verificada pela capacidade dos materiais em impedir a penetração do azul de metileno a $1 \%$. Ocorreu infiltração em $56 \%$ dos dentes selados com amálgama, 
$20 \%$ com os selados com Super-EBA e nenhuma infiltração no grupo do MTA.

DALÇÓQuio et al. ${ }^{21}$, em 2001, compararam a infiltração do azul de metileno em 120 dentes humanos extraídos, que foram retrobturados com MTA, Ketac-Fil, IRM e cianoacrilato. Foram realizadas apicectomias e cavidades retrógradas com profundidade de três milímetros. Todos os dentes foram imersos no corante azul de metileno a $1 \%$ e a infiltração foi medida por meio de espectrofotometria, após 48 horas, sete e 60 dias. Não houve diferença estatisticamente significante entre os materiais nos períodos de 48 horas e 60 dias, mas no período de sete dias existiu uma diferença significante, sendo que o MTA mostrou o melhor resultado seguido pelo Ketac-Fil, cianoacrilato e IRM respectivamente.

GONÇALVES ${ }^{35}$, em 2002, avaliou a capacidade de selamento apical de quatro técnicas de vedamento retrógrado, empregando-se dois materiais retrobturadores diferentes. Foram utilizados 90 dentes humanos, que tiveram seus canais instrumentados e obturados. Após a apicectomia e impermeabilização da superfície dentária, as raízes foram divididas em nove grupos. As técnicas utilizadas foram as seguintes: obturação retrógrada (grupos l e II), retroinstrumentação com retrobturação (grupos III e IV), retroinstrumentação com retrobturação associada à obturação retrógrada (grupos $\mathrm{V}$ e VI), canalização (grupo VII e VIII). Cada técnica utilizou os materiais Super-EBA e o MTA. As raízes foram imersas em Rhodamine B 2\%, por 72 horas. Após esse período, as raízes foram avaliadas com auxilio de um microscópio óptico. Na comparação dos materiais retrobturadores empregados nas diferentes técnicas estudadas, 
observou-se que os mesmos não apresentaram diferença estatisticamente significante.

Com o objetivo de avaliarem o selamento marginal proporcionado pelo MTA, IRM, Super-EBA, ionômero de vidro e amálgama de prata com verniz (Copalite), BERNABÉ et al. ${ }^{12}$, em 2002, conduziram estudo "in vitro" com 70 dentes humanos uniradiculares recém extraídos. Os três milímetros apicais dos dentes foram seccionados, os canais instrumentados e após a instrumentação, os canais foram preenchidos com cimento de óxido de zinco e eugenol. As raízes, com exceção da superfície apicectomizada receberam externamente uma camada de Araldite. Retrocavidades de três milímetros de profundidade foram confeccionadas e preenchidas com os materiais pesquisados. A infiltração foi avaliada após a imersão dos dentes em azul de metileno a $2 \%$ por 24 horas. A análise dos resultados mostrou diferença significante entre os materiais, sendo que o IRM apresentou o maior índice de infiltração e o MTA o menor. Já o ionômero de vidro, o super-EBA e o amálgama de prata com Copalite apresentaram resultados semelhantes entre si.

ANDELIN et al. ${ }^{5}$, em 2002, compararam a penetração de corante via apical em dentes totalmente preenchidos com MTA, e que após a obturação, sofreram apicectomia, com dentes que somente após a apicectomia foram retrobturados com MTA. Para essa comparação utilizaram 46 dentes humanos extraídos divididos em dois grupos experimentais de 20 espécimes cada e seis dentes divididos em dois grupos controle o positivo e o negativo. Os dentes do grupo I foram totalmente obturados com MTA, os do grupo II foram obturados com guta-percha e cimento Kerr EWT. Os espécimes de ambos os grupos tiveram três 
milímetros de seus ápices removidos. Os dentes do grupo II tiveram retrocavidades de três milímetros preparadas e preenchidas com MTA. A superfície externa dos dentes foi impermeabilizada com esmalte de unha. Todos os dentes foram colocados em contato com tintura da Índia por 48 horas, e após esse período foram seccionados em duas partes e a penetração apical de corante foi avaliada, não havendo diferença estatisticamente significante entre os grupos.

SILVA NETO et al. $^{70}$, em 2003, avaliaram a capacidade seladora do MTA Pro Root, do MTA Angelus e do Super-EBA quando utilizados como materiais retrobturadores. Para tanto, utilizaram-se de 34 dentes humanos extraídos que tiveram as coroas dentais removidas os canais radiculares instrumentados e que foram obturados com cimento de óxido de zinco e eugenol e cone único de guta-percha. Após 48 horas da obturação do canal radicular, foi realizada apicectomia e as cavidades retrógradas foram confeccionadas com pontas ultrasônicas. A superfície externa de todas as raízes sofreu impermeabilização com Araldite. Os espécimes foram divididos em três grupos experimentais em função do material retrobturador utilizado e em dois grupos controles. Concluídas as retrobturações, as raízes foram imersas em solução aquosa de Rhodamine $\mathrm{B}$ a $0,2 \%$ e mantidas em estufa a $37^{\circ} \mathrm{C}$ por 48 horas. Após esse período, realizou-se o desgaste longitudinal da face mesial radicular expondo a retrobturação e a marca da infiltração marginal. Os autores observaram que todos os materiais permitiram infiltração apical e que não houve diferença estatística significante entre eles.

A penetração de corante em dentes retrobturados foi também avaliada por ARAÚjo et al. ${ }^{7}$ em 2004. Os autores 
utilizaram 66 pré-molares inferiores humanos, extraídos, os quais foram instrumentados e posteriormente obturados com cimento Endomethasone e cones de guta pecha. Após a obturação dos canais radiculares, removeram-se os três milímetros apicais e realizaram cavidades retrógradas de três milímetros de profundidade com pontas de ultra-som. Os dentes foram divididos aleatoriamente em três grupos, um para cada material testado (MTA Pro Root, MTA Angelus e IRM), retrobturados e imersos em tinta nanquim, por 12 horas a $37^{\circ} \mathrm{C}$. As duas marcas comerciais de MTA apresentaram resultados semelhantes frente à infiltração apical de corantes e ambas foram superiores ao IRM.

TORABINEJAD et al. $^{83}$, em 1995, testaram o amálgama livre de zinco, Super-EBA, IRM e MTA em obturações retrógradas, verificando a capacidade seladora desses materiais frente ao Staphylococcus epidermidis. Utilizaram 56 dentes humanos extraídos, os quais foram instrumentados e após a ressecção de três milímetros apicais, foram confeccionadas retrocavidades as quais foram seladas com os materiais testados. Para impedir a infiltração bacteriana através das superfícies radiculares todos os dentes tiveram as paredes laterais impermeabilizadas com esmalte de unha. Os ápices dentais foram imersos em um frasco contendo meio de cultura estéril e os canais radiculares foram preenchidos com 0 Staphylococcus epidermidis. O monitoramento da passagem da bactéria pelo material retrobturador foi realizado diariamente. $O$ grupo cujos dentes foram retrobturados com o MTA apresentou o menor índice de infiltração. Não houve diferença estatística entre os demais grupos estudados. 
Em 1998, FISCHER; ARENS; MILLER ${ }^{30}$ analisaram a infiltração da bactéria Serratia marcescens, em dentes submetidos à apicectomia, confecção de retrocavidades de três milímetros e obturação retrógrada com amálgama sem zinco, IRM, Super-EBA, ou MTA. Foram utilizados 48 dentes uniradiculares humanos extraídos divididos em quatro grupos de 10 espécimes onde se utilizou os cimentos testados e em dois grupos de quatro espécimes que serviram como controle positivo e negativo. A superfície lateral de todos os dentes foi impermeabilizada com esmalte de unha. Três milímetros apicais dos espécimes foram imersos em meio de cultura e o canal radicular foi preenchido com a bactéria. Quatro vezes por semana era realizada a observação dos espécimes para a verificação da turvação do meio de cultura. Os autores concluíram que o MTA foi o material mais efetivo em impedir a penetração bacteriana.

ADAMO et al. ${ }^{1}$, em 1999, avaliaram comparativamente a infiltração bacteriana em dentes humanos extraídos quando retrobturados com MTA, Super-EBA, resina composta TPH mais adesivo dentinário (Pro Bond) e amálgama (com e sem aplicação de adesivo Pro Bond). Sessenta dentes humanos uniradiculares foram aleatoriamente divididos em cinco grupos, um para cada material testado. Os dentes foram instrumentados, apicectomizados e os materiais inseridos em retrocavidades de três milímetros de profundidade feitas com ultra-som. Esmalte de unha foi aplicado em toda superfície radicular externa, exceto sobre os materiais testados. As amostras foram esterilizadas em óxido de etileno. Cerca de três milímetros das raízes foram imersos em meio de cultura BHI com indicador fenol vermelho. O canal radicular de todos os dentes foi preenchido com uma suspensão de Streptococcus salivarius. 
0 meio de cultura foi observado diariamente para verificação de mudança de cor indicativa de contaminação bacteriana. O período máximo de observação foi de 12 semanas. Os autores concluíram que, sob as condições do estudo, não houve diferença estatisticamente significante no valor de microinfiltração entre os cinco grupos testados.

Utilizando-se também de bactérias MANGIN et al. ${ }^{54}$, em 2003, avaliaram capacidade seladora do MTA, Super-EBA e de um cimento a base de hidroxiapatita frente à infiltração bacteriana via apical. Foram utilizados 40 dentes humanos extraídos, divididos aleatoriamente em três grupos de 10 espécimes, um grupo para cada material testado e em dois grupos controles de cinco espécimes cada. A bactéria selecionada para o teste de infiltração foi o Enterococcus faecalis. Seccionaram as coroas dentais, as raízes foram instrumentadas e apicectomizadas em três milímetros. Foram confeccionadas retrocavidades de três milímetros de profundidade com pontas de ultra-som as quais foram retrobturadas com os materiais testados, as raízes permaneceram estocadas em uma esponja embebida com solução salina por 48 horas a $37^{\circ} \mathrm{C}$. Após esse período, as raízes foram fixadas no aparato utilizado para mensurar a infiltração. Os materiais testados não apresentaram diferença estatisticamente significante.

LEIMBURG et al. ${ }^{49}$, em 2004, utilizaram o Enterococcus faecalis para avaliarem a capacidade seladora do MTA branco em obturações retrógradas. Foram utilizados 34 dentes humanos extraídos os quais foram instrumentados e apicectomizados. Os dentes foram divididos em 3 grupos experimentais de 10 espécimes, os grupos eram divididos de 
acordo com a profundidade da retrocavidade realizada nos espécimes. Grupo I - Retrocavidades com um milímetro de extensão; Grupo II - Retrocavidades com dois milímetros de extensão; Grupo II - Retrocavidades com três milímetros de extensão. Os ápices dentais foram imersos em meio de cultura estéril e $150 \mu \mathrm{L}$ de meio de cultura com Enterococcus faecalis foi inoculada nos canais radiculares. Os espécimes foram checados aos $10,20,30,40$ e 50 dias para a verificação da turvação do meio de cultura, tal turvação era o indicativo da passagem das bactérias pelo material retrobturador. Do meio de cultura que apresentasse turvação era removida uma alíquota para a realização do PCR (reação de cadeia polimerase). Não houve diferença estatística entre os grupos testados.

\section{Em 2001, SCHEERER; STEIMAN; COHEN $^{68}$} avaliaram comparativamente a microinfiltração bacteriana "in vitro" no MTA, Super-EBA e no Geristore quando utilizados em obturações retrógradas. Cem dentes humanos, uniradiculares, foram aleatoriamente divididos em três grupos de 30 espécimes que receberam os materiais experimentais e em dois grupos controles. Os dentes foram instrumentados, apicectomizados e os materiais retrobturadores inseridos em retrocavidades de três milímetros de profundidade confeccionadas com ultra-som. Esmalte de unha foi aplicado em toda superfície radicular externa, exceto sobre a superfície apicectomizada. As amostras foram esterilizadas em autoclave. Cerca de três milímetros das raízes foram imersos em caldo de carne e mantidas a $37^{\circ} \mathrm{C}$. Os canais radiculares de todos os dentes foram preenchidos com uma suspensão de Prevotella nigrescens. O meio de cultura foi observado três vezes por semana para verificação de mudança de cor indicativa de contaminação bacteriana. O período máximo de observação foi de 47 dias. Um espécime do grupo 
retrobturado com Super EBA apresentou infiltração, não existiu infiltração em nenhum espécime dos outros dois grupos. Os autores concluíram que, sob as condições do estudo, não houve diferença estatisticamente significante no valor da microinfiltração entre os três materiais testados.

A capacidade do MTA e do óxido de zinco eugenol consistente em impedir a infiltração bacteriana quando utilizados como material retrobturadores foi avaliada por ROCHA $^{66}$ em 2003. Utilizaram 48 raízes de quatro cães. Constituíram-se 4 grupos experimentais: Grupo I - Dentes com canais radiculares expostos ao meio bucal e a obturação retrógrada realizada com o cimento de óxido de zinco e eugenol consistente; Grupo II Dentes com canais radiculares expostos ao meio bucal e a obturação retrógrada realizada com MTA; Grupo III - Dentes com canais radiculares obturados e coroas seladas com amálgama e a obturação retrógrada realizada com o cimento de óxido de zinco e eugenol consistente e Grupo IV - Dentes com canais radiculares obturados e coroas seladas com amálgama e a obturação retrógrada realizada com MTA. Após 180 dias dos procedimentos cirúrgicos, os animais foram mortos, os maxilares removidos e fixados em solução de formol a 10\%. Realizou-se então a descalcificação das peças e posterior processamento histológico, sendo os cortes corados pelas técnicas da hematoxilina e eosina e Brown \& Brenn. O MTA independentemente do tipo de tratamento executado, se canais selados ou não, apresentou resultados mais favoráveis àqueles exibidos pelo OZE consistente. Segundo o autor os efeitos da infiltração marginal coronária são minimizados com o emprego de um material retrobturador eficiente do ponto de vista de selamento marginal, como é o MTA. Dos materiais retrobturadores utilizados, o único que estimulou a deposição de 
tecido cementário em íntimo contato com o material selador foi o MTA.

TSELNIK; BAUMGARTNER; MARSHALL ${ }^{90}$, em 2004, testaram a capacidade seladora do MTA Pro Root branco e cinza e o cimento Fuji quando utilizados como barreira a infiltração bacteriana via coronária. Os autores utilizaram 78 dentes humanos extraídos, os quais foram instrumentados e posteriormente obturados com um cone de guta-percha e cimento Kerr EWT. Após a obturação dos canais radiculares foi colocada uma camada de três milímetros dos cimentos sobre a embocadura do canal radicular. Para impedir a infiltração bacteriana através da superfície lateral, todos os dentes tiveram as paredes laterais impermeabilizadas com esmalte de unha. Os ápices foram imersos em um frasco contendo meio de cultura esterilizado e os dentes foram recobertos com o meio de cultura com o Staphylococcus epidermidis. O monitoramento da passagem da bactéria pelo material selado e foi realizado diariamente. Não houve diferença estatisticamente significante entre os dois tipos de MTA estudados. Os autores relataram ainda que a única diferença existente entre os dois tipos de MTA é a redução da quantidade de ferro no MTA branco.

SIQUEIRA et al. ${ }^{72}$, em 2004, avaliaram comparativamente a microinfiltração bacteriana "in vitro" no MTA Pro Root, MTA Angelus cinza, cimento Portland e no MBPC quando utilizados em obturações retrógradas. Noventa e dois dentes humanos uniradiculares, foram aleatoriamente divididos em quatro grupos de 20 espécimes que receberam os materiais experimentais e em dois grupos controles. Os dentes tiveram as coroas removidas e posteriormente foram instrumentados, apicectomizados, e os materiais retrobturadores inseridos em 
retrocavidades de três milímetros de profundidade. Para impedir a passagem de bactérias por canais laterais aplicou-se Araldite em toda superfície radicular externa, exceto sobre a superfície apicectomizada. As raízes foram inseridas em tubos eppendorf, fixadas com Araldite e mantidas em ambiente úmido por 15 dias, sendo então esterilizadas em óxido de etileno. O conjunto (raiz e tubo de microcentrífuga) foi montado em frascos tipo penicilina. O Enterococcus faecalis foi inoculado dentro do tubo de microcentrífuga. $\mathrm{O}$ aparato permaneceu em estufa a $37^{\circ} \mathrm{C}$ por 50 dias. Nesse período ocorreu infiltração em apenas um espécime de cada grupo experimental.

Além da verificação da capacidade seladora frente à infiltração bacteriana, existem na literatura experimentos que testaram a capacidade do MTA em impedir a passagem de endotoxinas. Para tanto TANG; TORABINEJAD; KETTERING ${ }^{\mathbf{7 8}}$, em 2002, comparam "in vitro" a capacidade do MTA, IRM, SuperEBA e amálgama em prevenir a penetração de endotoxinas bacterianas quando utilizados como materiais retrobturadores. Utilizaram 104 raízes extraídas as quais depois de instrumentadas foram divididas em quatro grupos experimentais de 23 espécimes cada e em três grupos controles com quatro espécimes cada. Foram preparadas retrocavidades com três milímetros de profundidade as quais foram preenchidas com os materiais experimentais. As raízes foram fixadas em tubos de microcentrífuga dentro dos quais foi colocado a endotoxina, todo esse conjunto (tubo de microcentrífuga, raiz retrobturada e endotoxina) foi fixado em um frasco de vidro contendo meio de cultura. Avaliaram-se os materiais pelo período de uma, duas, seis e 12 semanas, e a cada período experimental retirava-se uma alíquota do meio de cultura para a verificação da presença da endotoxina, o que indicaria a sua passagem pelo material 
retrobturador. Os resultados demonstraram que o MTA foi melhor em todos os períodos quando comparado ao IRM e ao amálgama. Com relação ao Super-EBA o MTA foi melhor nos períodos experimentais de duas, seis e 12 semanas, no período de uma semana esses materiais não apresentaram diferença significante.

A atividade antimicrobiana do amálgama, óxido de zinco eugenol, Super-EBA e do MTA sobre nove bactérias facultativas e sete anaeróbias estritas, foi verificada por TORABINEJAD et al. ${ }^{86}$, em 1995. Após a inserção das bactérias no meio de cultura, os materiais foram manipulados e colocados imediatamente ou 24 horas após a espatulação em contato com as bactérias e incubados por 24 ou 48 horas. O MTA apresentou atividade antibacteriana somente sobre cinco tipos de bactérias facultativas e nenhum efeito sobre bactérias anaeróbias estritas. O amálgama não apresentou propriedade antibacteriana em nenhuma espécie de bactéria testada, e o Super-EBA foi efetivo contra três tipos de bactérias facultativas e sobre dois tipos de bactérias anaeróbias estritas e o óxido de zinco eugenol foi efetivo em cinco tipos de bactérias facultativas e sobre dois tipos de bactérias anaeróbias estritas.

ESTRELA et al. ${ }^{27}$, em 2000, avaliaram a ação antimicrobiana do MTA, cimento Portland, pasta de hidróxido de cálcio e do Sealapex Foram utilizadas quatro cepas bacterianas: Staphylococcus aureus, Enterococcus faecalis, Pseudomonas aeruginosa, Bacillus subtilis e um fungo a Candida albicans e uma associação destes microrganismos. A composição do MTA e de dois cimentos Portland também foram analisados. Os autores concluíram que a atividade antimicrobiana da pasta de hidróxido de cálcio foi superior a todas as outras substâncias pesquisadas 
apresentando zonas de inibição de seis a 9,5 milímetros e zonas de difusão com 10 a $18 \mathrm{~mm}$. O MTA, o cimento Portland e o Sealapex apresentaram somente zonas de difusão e entre esses - Sealapex mostrou a maior. Quanto à análise química, os cimentos Portland continham as mesmas substâncias químicas que o MTA, exceto o óxido de bismuto que faz parte do MTA e não foi encontrado nos cimentos Portland.

AL-NAZHAN; AL-JUDAI ${ }^{4}$, em 2004, avaliaram a atividade antifúngica do MTA frente à Candida albicans. Os autores prepararam corpos de prova com MTA recentemente espatulado e com MTA espatulado há 24 horas. Esses corpos de prova foram depositados dentro de tubos pyrex contendo meio de cultura com Candida albicans e incubados a $37^{\circ} \mathrm{C}$. As avaliações foram realizadas após uma hora, um dia e três dias após os corpos de provas serem colocados em contato com a suspensão com o fungo. Tanto o MTA recém espatulado quanto o espatulado há 24 horas mostraram-se eficientes em impedir o crescimento da Candida albicans somente após um ou três dias de contato.

A contaminação bacteriana e fúngica presente no MTA Angelus (cinza e branco) e no cimento Portland de um saco recém aberto e de outro aberto há dois meses foi avaliada por DUARTE et al. $^{25}$, em 2002. Para a realização do teste bacteriológico os cimentos testados foram incubados assepticamente em três mililitros de caldo $\mathrm{BHI}$ por 24 horas a $37^{\circ} \mathrm{C}$, após esse período inicial esses caldos contendo os cimentos foram colocados nos seguintes meios: Ágar Mac Conkey, Ágar Manitol, Ágar sangue, Ágar Cetremide, Ágar MEnterococcus e incubados por 24 horas a $37^{\circ} \mathrm{C}$. Para a realização do teste micológico as amostras foram incubadas em 
três mililitros de caldo Sabouraud acrescido de cloranfenicol e mantidas a $25^{\circ} \mathrm{C}$ por 72 horas, após esse período as amostras foram plaqueadas nos seguintes meios: Ágar Sabouraud, Ágar Batata-Dextrose e Ágar Mycobiotic as placas foram incubadas por 15 dias a $25^{\circ} \mathrm{C}$. Não ocorreu crescimento de microrganismos em nenhuma das placas.

TORABINEJAD et al. $^{85}$, em 1995, realizaram um estudo para determinar a composição química, $\mathrm{pH}$ e radiopacidade do MTA cinza e também comparar: tempo de presa, solubilidade e resistência à compressão do MTA em relação ao amálgama, Super-EBA e IRM. Os exames demonstraram que o MTA é composto de finas partículas hidrofílicas e seus principais componentes são: silicato tricálcio, aluminato tricálcio, óxido tricálcio e óxido de silicato, e pequenas quantidades de outros óxidos minerais e do óxido de bismuto que possui a propriedade de the conferir radiopacidade. $\mathrm{O}$ pH inicial era de 10,2 e aumentou para 12,5 três horas após ser misturado a água. O MTA apresentou maior radiopacidade que o Super-EBA e IRM. O tempo de presa do MTA foi de duas horas e 45 minutos, e em 24 horas sua resistência à compressão foi de $40 \mathrm{MPa}$, que aumentou para $67 \mathrm{MPa}$ após 21 dias. Com exceção do IRM nenhum dos materiais testados apresentou solubilidade.

REGALADO et al. ${ }^{65}$, em 2002, avaliaram as variações de $\mathrm{pH}$ do MTA Pro Root, MTA Angelus, cimento Portland cinza e cimento Portland branco. Os cimentos foram espatulados na proporção de $0,18 \mathrm{mg}$ de pó para $60 \mu \mathrm{L}$ de água deionizada; e colocados em cilindros de polietileno com cinco milímetros de comprimento. Os cilindros preenchidos com os materiais testados foram imediatamente armazenados individualmente em 
frascos contendo cinco mililitros de água deionizada. Utilizou-se cinco amostras de cada cimento para realizar as leituras de $\mathrm{pH}$, através do pHmetro Orion. As leituras foram realizadas nos tempos de 10 minutos, 15 minutos, 30 minutos, uma hora, duas horas, seis horas, 24 horas e 48 horas. O Portland branco teve um $\mathrm{pH}$ menor que os outros cimentos com diferença estatisticamente significante nos tempos 15 e 30 minutos. Nos demais tempos não houve diferença estatística significante entre os materiais.

FUNTEAS et al. ${ }^{32}$, em 2003, compararam a composição química do MTA e do cimento Portland e verificaram uma similaridade significante, com exceção do bismuto que não foi detectado no cimento Portland. Os autores concluíram que não há diferenças significativas entre 14 diferentes elementos presentes nos dois materiais.

A adaptação marginal do Super-EBA, IRM, amálgama e do MTA em retrobturações foi analisada por TORABINEJAD et al. ${ }^{84}$, em 1995, utilizando o microscópico eletrônico de varredura. Foram utilizados 88 dentes uniradiculares humanos extraídos. Após a obturação convencional com guta-percha e cimento, os ápices foram removidos e cavidades de dois milímetros de profundidade foram confeccionadas e preenchidas com os materiais testados. A comparação dos espaços observados microscopicamente entre os materiais retrobturadores e a dentina evidenciou que o MTA obteve a melhor adaptação marginal.

ASGARY et al. $^{8}$, em 2005, foram os primeiros a realizarem um estudo para a verificação das diferenças existentes na composição química do MTA branco e do MTA 
cinza. As principais diferenças encontradas entre os dois cimentos foram as maiores concentrações de óxido de alumínio $(+122 \%)$, óxido de magnésio $(+130 \%)$ e principalmente óxido de ferro $(+1000 \%)$ presentes na composição do MTA cinza. Por outro lado os dois tipos de cimento possuem como seus principais componentes o óxido de cálcio, sílica e o óxido de bismuto.

MORANDI ${ }^{60}$, em 1999, avaliou o reparo após a realização de apicectomia e obturação retrógrada com cimento de óxido de zinco e eugenol consistente, IRM, Super-EBA e MTA em 32 pré-molares de cães. Após a apicectomia, aguardou-se 180 dias para a morte dos animais. Os resultados demonstraram que o MTA, Super-EBA e o IRM apresentaram resultados semelhantes entre si e superiores aos obtidos com o cimento de óxido de zinco e eugenol consistente. O MTA foi o único material que estimulou a formação de cemento em íntimo contato com o material retrobturador.

FARACO JÚNIOR ${ }^{28}$, em 1999, avaliou microscopicamente a resposta da polpa dental de cães ao capeamento com sistema adesivo (Single Bond), cimento de hidróxido de cálcio (Dycal) e MTA branco e cinza. As polpas foram expostas de modo asséptico, capeadas com o material testado, os dentes capeados com sistema adesivo foram selados com resina composta e os demais com óxido de zinco e eugenol. Os animais foram mortos, após 60 dias do procedimento clínico, e os dentes processados para obtenção de cortes histológicos, corados pelas técnicas da hematoxilina e eosina e de Brown \& Brenn. Os resultados obtidos foram ordenados da melhor para a pior resposta tecidual da seguinte forma: 1) MTA cinza; 2) MTA branco; 3) Dycal e 4) Sistema adesivo. A principal diferença 
encontrada entre o MTA branco e o cinza foi quanto à espessura do tecido mineralizado formado que foi mais espessa quando se utilizou o MTA cinza.

PARIROKH et al. ${ }^{62}$, em 2005, também realizaram capeamento pulpar direto em dentes de cães com o MTA cinza e o MTA branco. Foram utilizados 24 dentes de quatro cães, 12 dentes para cada cimento. Os autores confeccionaram uma exposição pulpar de um milímetro de diâmetro, o sangramento foi controlado com irrigações de solução salina e imediatamente capeada com um dos tipos de MTA. Os cães foram divididos em dois grupos: Grupo I - Mortos após uma semana da realização do capeamento, Grupo II - Mortos duas semanas após a realização do capeamento. Os espécimes do Grupo I apresentaram uma fina, porém completa ponte de dentina em quatro espécimes do MTA branco em três espécimes do MTA cinza, as pontes de dentina eram mais largas na periferia do que no centro da exposição, ocorreu também uma inflamação moderada com a presença de macrófagos e linfócitos. Nos espécimes do Grupo II pode se observar à presença de ponte de dentina em todos os seis espécimes do grupo do MTA branco e em quatro espécimes do MTA cinza, a espessura da ponte de dentina aumentou e o número de células inflamatórias diminui. Os autores relataram que não houve diferença significante entre os dois tipos de MTA nesse grupo.

A resposta do tecido pulpar de cães frente ao MTA e cimento Portland foi estudada também, por MENEZES et al ${ }^{56} \mathrm{em}$ 2004. Para tanto realizaram pulpotomias em 76 dentes divididos em quatro grupos, um para cada cimento testado: MTA Pro Root, MTA Angelus e os cimentos Portland e Portland branco. As polpas foram expostas assepticamente e o material foi colocado 
diretamente sobre a polpa. Os animais foram mortos 120 dias após a realização das pulpotomias. A análise microscópica mostrou que as reações teciduais aos quatro materiais foram semelhantes e que os quatro materiais favoreceram a formação de tecido duro sobre as polpas. Os autores não observaram diferença nas reações inflamatórias causadas pelos materiais sobre o tecido pulpar.

BERNABÉ et al. ${ }^{*}$ em 2004, avaliaram o comportamento dos tecidos periapicais de dentes de cães, com lesões periapicais, submetidos à obturação retrógrada convencional, considerando-se o tipo de material retrobturador e a utilização ou não do microscópio clínico odontológico, utilizando pré-molares superiores e inferiores de cães, com lesões periapicais crônicas. Foi realizado o acesso cirúrgico apical para que se efetuasse a curetagem periapical, apicectomia e preparo de retrocavidades com emprego do ultrasom. As obturações retrógradas foram realizadas com o cimento de Sealapex acrescido de óxido de zinco, sendo na metade dos espécimes realizados com auxilio do microscópio cirúrgico e a outra metade sem auxilio do microscópio. Após 180 dias da realização dos procedimentos cirúrgicos os animais foram mortos para a realização da avaliação microscópica das peças. Os autores concluíram que não houve diferenças significativas entre os grupos experimentais com e sem o emprego do microscópio odontológico. A ocorrência de casos com selamento biológico foi atribuída ao emprego do cimento obturador Sealapex consistente, que possuiria a propriedade de estimular a formação de tecido duro.

\footnotetext{
${ }^{*}$ BERNABÉ, P.F.E. et al. Faculdade de Odontologia de Araçatuba - UNESP. (Trabalho Concluído)
} 
LUIZ ${ }^{52}$, em 2003, avaliou a reparação apical e periapical após obturação retrógrada em dentes de cães com reação periapical crônica empregando diferentes materiais retrobturadores. Foram utilizados 48 canais radiculares com lesões periapicais, os canais radiculares foram parcialmente obturados, sem a realização do preparo biomecânico. Em seguida foi realizada a cirurgia parendodôntica com obturação retrógrada empregando como materiais retrobturadores o Sealer 26, o Sealapex acrescido de óxido de zinco (Sealapex consistente) ou o Mineral Trióxido Agregado (MTA). Decorrido o período de 180 dias, os animais foram mortos e as peças submetidas ao processamento histológico. Os resultados da análise microscópica demonstraram que, os grupos que empregaram o Sealer 26, Sealapex consistente ou MTA apresentaram resultados semelhantes de reparação apical e periapical. Os autores afirmam que os três cimentos estudados apresentam potencial para serem empregados como materiais retrobturadores.

\section{2 -Sealapex}

HOLLAND et al. ${ }^{41}$, em 1991, avaliaram a infiltração marginal de corantes após a obturação do canal radicular de dentes humanos extraídos, com diferentes cimentos obturadores. Os cimentos estudados foram os seguintes: óxido de zinco eugenol, Fill Canal, Rickert, AH26, Sealapex, CRCS, New B2 e um cimento experimental desenvolvido pelo departamento de Endodontia de Araçatuba. Todos os dentes tiveram suas coroas removidas e foram instrumentados até que uma lima tipo kerr $\mathrm{n}^{\circ}$. 40 ultrapassasse um milímetro do forame apical, após a instrumentação as raízes foram obturadas pela técnica da 
condensação lateral. Concluída a obturação, as raízes foram impermeabilizadas com Araldite e imersas em água por 24 horas ou 75 dias. Após esses períodos, as raízes foram imersos em solução de azul de metileno a $2 \%$ sob vácuo. Os autores observaram que a infiltração marginal foi maior no grupo de 75 dias do que a observada no grupo de 24 horas para todos os cimentos obturadores testados e que o Sealapex mostrou os menores índices de infiltração em ambos os períodos testados.

Ainda com o propósito de avaliarem a infiltração marginal de corantes em dentes humanos extraídos, preparados mecanicamente e obturados HOLLAND et al. ${ }^{42}$, em 1996, utilizaram a mesma metodologia do trabalho anterior, porém no presente trabalho os espécimes ficaram apenas 24 horas imersos em água antes de serem colocados em contato com o corante. Os cimentos utilizados foram: Sealapex, Apexit, Sealer, CRCS, e óxido de zinco e eugenol. Os autores observaram que os cimentos a base de hidróxido de cálcio exibiram melhor vedamento do canal radicular que o cimento de óxido de zinco e eugenol e que dentre os cimentos à base de hidróxido de cálcio o Sealapex apresentou o melhor vedamento.

CANALDA-SAHLI et al. ${ }^{18}$, em 1992, avaliaram o selamento apical proporcionado pelos cimentos endodônticos: Endomethasone, Tubliseal, AH26, Diaket, Sealapex e CRCS utilizando o método de penetração do radioisótopo ${ }^{99} \mathrm{TC}$. Foram utilizados 150 dentes humanos extraídos, as coroas foram removidas e os canais radiculares instrumentados. As raízes foram divididas em oito grupos, sendo seis grupos experimentais, um para casa cimento testado, e dois grupos controles. Os canais foram obturados pela técnica da condensação lateral utilizando-se guta-percha e um dos 
cimentos testados, após a obturação as raízes permaneceram incubadas a $37^{\circ} \mathrm{C}$, a $100 \%$ de umidade por 10 dias para que todos os cimentos tomassem presa. Após esse período as raízes tiveram dois milímetros de seus ápices imersos no radioisótopo por cinco horas. O Sealapex apresentou os menores índices de infiltração entre todos os cimentos testados.

SIQUEIRA JUNIOR; GARCIA FILHO $^{73}$, em 1994, testaram o selamento apical proporcionado por três cimentos à base de hidróxido de cálcio (Sealapex, CRCS e Sealer 26). Utilizaram 30 dentes humanos anteriores superiores recém extraídos, todos os dentes foram instrumentados até que uma lima tipo Kerr $\mathrm{n}^{\circ}$. 30 ultrapassasse um milímetro o ápice radicular. Após o preparo mecânico, os espécimes foram divididos em três grupos um para cada cimento testado. Os dentes foram obturados pela técnica da condensação lateral utilizando-se guta-percha e um dos cimentos estudados, impermeabilizados com uma camada de Araldite e duas camadas de esmalte de unha e imersos em solução de azul de metileno a $2 \%$, por sete dias a $37^{\circ} \mathrm{C}$. Decorrido este período, os dentes foram lavados e fraturados longitudinalmente para a mensuração das infiltrações. Os três cimentos estudados não promoveram um selamento hermético do forame apical e não apresentaram diferença estatisticamente significante entre si.

ANTÔNIO; MOURA ${ }^{6}$, em 1997, compararam "in vitro" o grau de infiltração marginal do corante azul de metileno em dentes obturados com guta-percha e quatro cimentos endodônticos: N-Rickert, AH26, Sealapex e Ketac-Endo. Utilizaram 95 dentes incisivos centrais superiores humanos extraídos que foram instrumentados e tiveram os forames padronizados por sucessivos alargamentos, até que uma lima 
tipo Kerr de número 30 ultrapasse em dois milímetros o forame apical. Os dentes foram impermebializados com cianoacrilato e imersos em solução de azul de metileno a $0,5 \%$, a $37^{\circ} \mathrm{C}$ em estufa por 72 horas. Decorrido este período, os dentes foram seccionados longitudinalmente no sentido mésio-distal para análise das infiltrações. O Ketac-Endo apresentou os maiores valores de infiltração, entre os demais cimentos não existiu diferença significante.

CAMPS; PASHLEY ${ }^{16}$, em 2003, compararam três técnicas de penetração de corante, para tanto utilizaram 40 dentes humanos extraídos. As coroas foram removidas e os canais radiculares instrumentados. Os espécimes foram então divididos aleatoriamente em quatro grupos. Os canais foram obturados com a técnica da condensação lateral com gutapercha e com um dos seguintes cimentos: Pulp canal sealer, Sealapex, AH Plus e Ketac-Endo. As seguintes técnicas de penetração de corante foram testadas: extração de corante, técnica de filtração de fluido e a técnica clássica. Os resultados da técnica clássica não demonstraram diferença significante entre os materiais testados, já as outras duas técnicas demonstraram que o Sealapex foi o material que apresentou maior penetração de corante. Segundo os autores a técnica clássica ainda é bastante utilizada devido à facilidade de realizá-la e de não necessitar de materiais sofisticados, porém as duas outras técnicas apresentam resultados mais confiáveis.

BRONG et al. $^{15}$, em 2004, avaliaram por meio de infiltração de corante, a capacidade seladora de quatro cimentos endodônticos em dentes humanos extraídos (Sealapex, Sealer 26, Endofill e Roekoseal). Foram utilizados 60 caninos superiores todos os dentes foram instrumentados até que uma 
lima Kerr $n^{\circ}$. 25 atingisse o ápice radicular. Após o preparo mecânico, os dentes foram obturados pela técnica da condensação lateral com guta-percha e um dos cimentos estudados e imersos em solução de azul de metileno a $2 \%$, por sete dias a $37^{\circ} \mathrm{C}$. Decorrido este período, os dentes foram lavados e fraturados longitudinalmente, para medir as extensões das infiltrações. O Sealapex foi o cimentou que apresentou os menores índices de infiltração de corante, entre os demais cimentos não houve diferença estatisticamente significante.

POMMEL et al. ${ }^{64}$, em 2003, avaliaram as propriedades de selamento apical de quatro cimentos endodônticos utilizando a técnica de filtração de fluído. Foram utilizados 48 dentes humanos extraídos. As coroas foram removidas e as raízes instrumentadas e divididas aleatoriamente em quatro grupos um para cada cimento testado. Os dentes foram obturados com a técnica da condensação lateral com gutapercha e com um dos seguintes cimentos: Sealapex, Pulp canal sealer, AH 26 e Ketac-Endo. Após a obturação, as raízes foram estocadas a $37^{\circ} \mathrm{C}$ por 24 horas em ambiente com $100 \%$ de umidade para que o cimento tomasse presa. Após esse período, os espécimes foram submetidos ao teste de infiltração. O Sealapex foi o cimento que apresentou maiores valores de infiltração apical.

Diferentemente dos trabalhos anteriores que utilizaram corantes para as avaliações de infiltração HAÏKEL et al. ${ }^{37}$, em 1999, avaliaram a penetração da lisozima radioativa ${ }^{125} \mathrm{I}$ em canais radiculares obturados com guta-percha e os cimentos Sealapex, Sealite e AH Plus. Os dentes ficaram submersos na solução por quatro diferentes períodos: um, sete, 14 e 28 dias. Em seguida os dentes foram cortados 
transversalmente em seis partes de $0,8 \mathrm{~mm}$ de espessura. $O$ cimento Sealapex e AH PLUS comportaram-se de maneira similar e foram superiores ao Sealite. Os autores afirmaram que quanto maior o tempo de exposição a lisozima maior será a infiltração da mesma nos cimentos.

BARKHORDAR ${ }^{9}$, em 1989, avaliou a atividade antimicrobiana de dez cimentos endodônticos sobre 0 Streptococcus sanguis e o Streptococcus mutans. Os cimentos testados foram o AH26, CRCS, Dentinol, Diaket, Endofil, Kerr pulp Canal Sealer, Nolgenol, Pulpdent, Sealapex e Tubliseal. Os cimentos foram colocados em placas de cultura contendo os referidos microrganismos e incubados em micro-aerofilia a $37^{\circ} \mathrm{C}$, as mensurações das zonas de inibição foram realizadas após dois, sete e 14 dias. Os resultados mostraram que todos os materiais obturadores inibiram parcialmente o crescimento de ambos os microrganismos. O Streptococcus sanguis apresentou zonas de inibição maiores que as do $S$. mutans para todos os cimentos testados com exceção do Diaket. Segundo os autores o tamanho das zonas de inibição não reflete necessariamente a atividade antibacteriana dos cimentos. A zona de inibição pode ser influenciada pelo poder de difusão do cimento. Cimentos que possuam partículas menores difundem-se mais rapidamente, portanto possuem maior zona de inibição.

CANALDA; PUMAROLA ${ }^{17}$, em 1989, também avaliaram a atividade antimicrobiana dos cimentos endodônticos CRCS, Sealapex, Endomethasone, Tubliseal e AH26, sobre o Streptococcus $\beta$-hemoliíticos, Stafilococcus aureus, Escherichia coli e Bacteroides fragilis. Cada suspensão bacteriana foi semeada separadamente em cinco placas de Petri contendo meio de cultura. Os cimentos foram espatulados de acordo com 
as recomendações dos fabricantes e impregnados em discos de papel os quais foram colocados sobre a superfície de cada placa e incubados a $37^{\circ} \mathrm{C}$. As mensurações das zonas de inibição foram realizadas após 48 e 96 horas. O Endomethasone foi o material que apresentou maiores zonas de inibição, os demais cimentos tiveram comportamento semelhante frente as bactérias analisadas.

HELING; CHANDER ${ }^{39}$, em 1996, avaliaram a ação antibacteriana dos cimentos Pulp Canal Sealer EWT, Sealapex, AH26, e Ketac-Endo frente ao o Enterococcus faecalis, em raízes de dentes bovinos preparadas, esterilizadas e posteriormente contaminadas com o microrganismo. Após a contaminação, os canais foram preenchidos com os cimentos estudados e os dentes divididos em dois grupos que foram estocados a $37^{\circ} \mathrm{C}$ em ambiente úmido: Grupo I - Dentes incubados por 24 horas, Grupo II - Dentes incubados por sete dias. Após estes períodos, removeu-se todo o cimento do interior dos canais. Posteriormente com o auxílio de uma broca foi realizada a remoção de pó de dentina das paredes dos canais radiculares. Esse pó de dentina foi coletado em um tubo de eppendorf e mergulhado no meio de cultura por 24 horas. Com exceção do Ketac-Endo no Grupo I os cimentos tiveram ação antimicrobiana nos dois períodos testados. O Sealapex teve maior ação antibacteriana aos sete dias que em 24 horas.

Com o intuito de avaliarem a atividade antimicrobiana de quatro cimentos endodônticos frente ao Enterococcus faecalis, MICKEL; NGUYEN; CHOGLE ${ }^{57}$, em 2003, impregnaram discos absorventes de papel com os cimentos Roth 811, Kerr EWT, Sealapex e AH-Plus. Cada disco impregnado com um tipo de cimento foi distribuído em placas de Petri contendo meio de 
cultura semeados com o Enterococcus faecalis. Após, a colocação dos discos as placas foram incubadas a $37^{\circ} \mathrm{C}$ por até 48 horas. As mensurações foram realizadas 24 e 48 horas após a incubação. O Roth 811 apresentou halos de inibição de um milímetro, seguido pelo Sealapex com halos de 0.8 milímetros e pelo Kerr EWT halos de com 0.5 milímetro o $\mathrm{AH}$-Plus não apresentou halos de inibição. Não existiu diferença no tamanho dos halos de inibição entre os dois períodos. Estatisticamente houve diferença entre os cimentos testados. Porém é importante ressaltar que os autores afirmaram que não existe uma maneira totalmente segura de determinar o poder antimicrobiano de um cimento em estudos "in vitro" e que os tamanhos das zonas de inibição dependem muito da solubilidade e difusibilidade do material estudado.

O Enterococcus faecalis foi também utilizado por FUSS; WEISS; SHALHAV ${ }^{31}$, em 1997, na avaliação da ação antibacteriana dos cimentos Roth, CRCS e Sealapex. Os cimentos foram preparados, colocados sobre uma placa de vidro. $10 \mu \mathrm{L}$ de uma suspensão de Enterococcus faecalis foi colocada sobre a superfície dos cimentos uma hora, 24 horas e sete dias após a espatulação. A bactéria permaneceu em contato com os cimentos por uma hora a $37^{\circ} \mathrm{C}$. Após esse período, adicionou-se meio de cultura para permitir o crescimento bacteriano. Os resultados mostraram que no grupo de uma hora após a espatulação os cimentos Roth e CRCS tiveram ação antibacteriana significativamente superior ao Sealapex. No grupo de 24 horas após a espatulação, o cimento Roth obteve ação antibacteriana superior ao CRCS e ao Sealapex. Porém no grupo no qual se utilizou o cimento sete dias após a espatulação, o Sealapex demonstrou significativa superioridade em relação ao CRCS e Roth. Diante dos resultados, os autores concluíram que 
a ação antibacteriana dos cimentos modifica-se de acordo com o período de tempo decorrido de sua espatulação.

ESTRELA et al. ${ }^{26}$, em 1995, comparam a ação antimicrobiana dos cimentos Sealapex, Sealer 26 e Apexit, pelo método da difusão radial em ágar. Os materiais foram testados em três culturas puras de bactérias: Escherichia coli, Pseudomonas aeruginosas e Enterococcus faecalis. Os cimentos foram espatulados, depositados no meio de cultura contendo os microrganismos e as zonas de inibição foram medidas logo depois da espatulação e 48 horas após. Os autores concluíram que nenhum dos três cimentos testados inibiu o crescimento dos referidos microrganismos em período algum, demonstrando total ausência de efeito antimicrobiano.

\section{DUARTE; WECKWERTH; MORAES ${ }^{23}$, em 1997,} avaliaram o poder antimicrobiano dos cimentos Endomethasone, AH26, Sealer 26, Sealer 26 acrescido de $5 \%$ e $10 \%$ de hexametilenotetramina, Sealapex e pasta aquosa de hidróxido de cálcio. Foi utilizado o método de difusão radial em placas de ágar e os microrganismos escolhidos foram o Staphylococcus aureus, Enterococcus faecalis, Streptococcus mutans, Pseudomonas aeruginosas, Klebsiella s.p. e Candida albicans. As leituras foram efetuadas 24 e 48 horas após a incubação em aerobiose e micro-aerofilia. O Endométhasone obteve o melhor desempenho apresentando ação contra todos os microrganismos. O AH26 foi mais efetivo que o Sealer 26 e este último aumentou seus valores de inibição com a adição de $5 \%$ ou 10\% de hexametilenotetramina. O cimento Sealapex e a pasta de hidróxido de cálcio não inibiram os microrganismos testados. 
SIQUEIRA JÚNIOR; GONÇALVES ${ }^{74}$, em 1996, compararam o efeito antimicrobiano dos cimentos Sealer 26, Sealapex, Apexit, Fillcanal e da pasta de hidróxido de cálcio com soro fisiológico contra seis bactérias anaeróbias estritas e duas anaeróbias facultativas, através do método de difusão radial em meio ágar. Após sete dias de incubação a $37^{\circ} \mathrm{C}$, observaram que o maior halo de inibição contra todas as bactérias foi verificado com o Fillcanal. O Sealer 26 inibiu a maioria das cepas excetuando-se a do Porphyromonas gengivalis e Porphyromonas endodontalis. 0 Sealapex inibiu apenas duas espécies de microrganismos e apresentou pequenos halos. A pasta de hidróxido de cálcio também apresentou baixa atividade antibactericida inibindo três tipos de microrganismos. O Apexit não inibiu nenhum dos microrganismos utilizados.

ÇOBANKARA et al. ${ }^{20}$, em 2004, avaliaram, através dos métodos de difusão em ágar e do método de contato direto, a capacidade antibacteriana dos cimentos Sealapex, RoekoSeal, Ketac-Endo, AH Plus e Sultan. Todos os cimentos foram preparados de acordo com as instruções dos fabricantes, a bactéria utilizada para a realização do estudo foi o Enterococcus faecalis. Para o teste de contato direto, os cimentos recém espatulados foram depositados em placas de vidro e $10 \mu \mathrm{L}$ da suspensão bacteriana foi depositada sobre cada cimento testado, mensurações do crescimento bacteriano foi observado por 19 horas; já para o teste de difusão em ágar alíquotas de $200 \mu \mathrm{L}$ da suspensão bacteriana foram semeadas em placas contendo BHI Ágar, e os cimentos recém espatulados foram depositados sobre as placas e incubados a $37^{\circ} \mathrm{C}$ por 24 horas ou sete dias, após esses períodos os halos de inibição presentes nas placas eram mensurados. De acordo com os resultados do teste de contato direto o Sealapex apresenta atividade 
antimicrobiana nas primeiras horas após a sua espatulação, o teste de difusão em ágar demonstrou não haver diferença entre os cimentos Sealapex, AH Plus e o Sultan já o RoekoSeal e o Ketac-Endo demonstraram os menores valores.

TAGGER; TAGGER; KFIR ${ }^{77}$, em 1988, avaliaram a liberação de íons cálcio e hidroxila dos cimentos Sealapex, CRCS, Hermetic. A liberação de íons cálcio foi avaliada pelo método da EGTA trituração e a liberação de íons hidroxila pela mensuração do $\mathrm{pH}$, foram observadas as liberações desses íons a cada 15 minutos durante duas horas. Os cimentos testados mostraram diferentes padrões de liberação de íons cálcio. O Sealapex apresentou liberação prolongada, gradativa e decrescente. O Hermetic teve grande liberação em curto período de tempo e o CRCS praticamente não liberou íons cálcio durante o período estudado, os autores relataram que a desintegração do Sealapex pode ser o motivo para a grande liberação de íons cálcio encontrada. A alcalinização do meio foi semelhante e prolongada para os todos os cimentos analisados.

A avaliação do $\mathrm{pH}$ e da liberação de íons cálcio de materiais endodônticos à base de hidróxido de cálcio foi realizada por LEONARDO et $\mathrm{al}^{50}$., em 1992. Os autores estudaram a pasta aquosa de hidróxido de cálcio e as pastas Calen, Calen com paramonoclorofenol canforado e Calasept e os cimentos CRCS e Sealapex. Foram realizadas leituras do $\mathrm{pH}$ e da liberação de íons cálcio em intervalos de tempo que variaram de cinco minutos a 60 dias. Nas pastas estudadas, Calasept e o Calem com e sem PMCC os valores de $\mathrm{pH}$ e de liberação de cálcio foram semelhantes em todos os períodos testados. Entre os dois cimentos testados, o Sealapex foi quem ofereceu maiores valores de pH e liberação de íons cálcio. 
DUARTE et al. ${ }^{24}$, em 2000, também avaliaram a liberação de íons cálcio e o pH dos cimentos endodônticos Sealapex, Sealer 26 e Apexit. Após a espatulação os cimentos foram colocados em tubos plásticos e cada tubo foi colocado dentro de frascos contendo água destilada e estocados a $37^{\circ} \mathrm{C}$, os autores mesuraram a liberação dos íons cálcio e o pH em quatro períodos, 24 horas, 48 horas, sete dias e 30 dias após a espatulação. O Sealapex apresentou a maior liberação de íons cálcio em todos os períodos estudados e os maiores valores de $\mathrm{pH}$ em 48 horas e sete e 30 dias.

Com o intuito de avaliarem a solubilidade dos cimentos endodônticos Sealapex, CRCS, Roth 801 e de uma pasta de hidróxido de cálcio com soro fisiológico, TRONSTAD; BARNET; FLAX ${ }^{89}$, em 1988, realizaram implantes, em tecido ósseo da mandíbula de cães. Tubos de Teflon foram preenchidos com os diferentes materiais e imediatamente colocados em perfurações realizadas no tecido ósseo mandibular. Após um período de 90 dias, os animais foram sacrificados, os resultados demonstraram que a pasta de hidróxido de cálcio havia sido completamente solubilizada o que propiciou o preenchimento dos tubos de teflon por tecido ósseo. O Sealapex foi parcialmente solubilizado, o CRCS e o Roth 801 não mostraram solubilização.

SCHÄFER; ZANDBIGLARI ${ }^{67}$, em 2003, compararam "in vitro" a solubilidade de oito cimentos endodônticos em saliva artificial e em água. Os cimentos estudados foram o Sealapex, AH26, AH Plus, RSA, RoekoSeal, Apexit, Aptal-Harz, Hetac Endo e Espe. Confeccionaram-se corpos de provas de todos os cimentos testados os quais foram imersos em saliva artificial ou água por diferentes períodos de tempos (30 segundos, um 
minuto, dois minutos, cinco minutos, 10 minutos, 20 minutos, uma hora, duas horas, 10 horas, 24 horas, 48 horas, 72 horas, 14 dias e 28 dias.) Antes da imersão os corpos de prova foram pesados por três vezes em uma balança de precisão. Todos os cimentos apresentaram redução no peso em ambos os meios testados, porém o Sealapex foi o cimento que apresentou maior redução.

HOLLAND; SOUZA ${ }^{40}$, em 1985, efetuaram um estudo microscópico utilizando 160 canais radiculares de oito cães e 80 canais radiculares de quatro macacos adultos. A remoção da polpa dental foi realizada em dois níveis, a um milímetro aquém do ápice radiográfico ou no ápice radiográfico. Os canais foram obturados com cimento Sealapex ou Kerr Pulp Canal Sealer e cones de guta-percha, ou somente com pasta de hidróxido de cálcio. O grupo controle consistiu de canais radiculares mantidos vazios. Após um período de 180 dias, os resultados observados em dentes de cães e macacos foram semelhantes e demonstraram que a obturação com Sealapex ou a pasta de hidróxido de cálcio induziram o fechamento apical pela deposição de cemento.

LEONARDO $^{51}$, em 1992, comparou a biocompatibilidade entre o Sealapex e o CRCS, utilizando dentes de cães que tiveram os seus ápices arrombados com uma lima Kerr $\mathrm{n}^{\circ}$. 30. Os canais foram instrumentados pela técnica escalonada, irrigados com solução de Dakin e obturados pela técnica da condensação lateral ativa. Esperou-se 12 meses para a morte dos animais e processamento histológico das peças. Os autores notaram que ambos os cimentos produziram inflamação crônica e deposição de tecido mineralizado na região apical. 
SILVA ${ }^{69}$, em 1995 avaliou os cimentos Sealapex, CRCS, Sealer 26 e Apexit de acordo com quatro diferentes metodologias: estudo microscópico da reparação apical e periapical, em dentes de cães, após biopulpectomia e obturação de canais radiculares; avaliação microscópica do tecido subcutâneo de ratos, após injeções das suspensões de cimentos obturados no período de dois, quatro, oito e 16 dias; avaliação da migração celular para cavidade peritoneal de camundongos nos períodos de seis a 24 horas, cinco, 15 e 30 dias e análise do $\mathrm{pH}$ e condutividade dos cimentos nos períodos de uma, duas, quatro, seis e 24 horas, cinco, 15 e 39 dias. Diante dos resultados, concluiu-se que entre os quatro cimentos estudados, o Sealapex foi o mais satisfatório, pois, ao exame microscópico em dentes de cães, evidenciou maior índice de selamento apical, além de processo de reparo apical em estágio mais avançado após 180 dias. No tecido conjuntivo subcutâneo demonstrou melhor compatibilidade tecidual e maior diferenciação celular. $\mathrm{Na}$ cavidade peritoneal induziu menor reposta inflamatória. Por fim, na análise físico-química, o Sealapex apresentou os maiores valores de $\mathrm{pH}$, condutividade e liberação de cálcio. A autora inferiu que a maior liberação de íons cálcio demonstra que os Sealapex possui maior solubilidade que os outros materiais testados. Neste estudo o Apexit, CRCS e Sealer 26 foram insatisfatórios.

Também utilizando dentes de cães TANOMARU FILHO et al. ${ }^{79}$, em 1998, avaliaram o reparo periapical de dentes necrosados e com lesão após o tratamento endodôntico realizado com os cimentos Sealapex ou Fill Canal. Após 270 dias da realização do tratamento endodôntico os animais foram mortos e as peças preparadas para avaliação microscópica. Os resultados obtidos com o Sealapex foram melhores que os 
obtidos com o Fill Canal, o grupo do Sealapex mostrou maior freqüência de selamentos parciais $73,7 \%$ contra $7,1 \%$ do grupo do Fill Canal, o grupo do Sealapex também apresentou os menores valores de inflamação.

Diferentemente dos quatro últimos autores que utilizaram animais em seus estudos, GUTMANN; FAVA ${ }^{36}$, em 1991, reportaram um caso clínico realizado em humano no qual utilizaram o Sealapex. Os autores acompanharam radiograficamente o processo de reparo de lesões periapicais existentes nos quatro incisivos superiores, portadores de polpas necrosadas, de um garoto de 14 anos. Todos os dentes foram instrumentados pela mesma técnica e obturados com gutapercha e Sealapex, a única diferença no tratamento dos dentes foi que os dois incisivos do lado direito tiveram o cimento extravasado propositalmente durante a obturação. Os autores relataram que após 12 meses ocorreram evidências de reparação em todos os dentes e que não existiu diferença entre os do lado com ou sem extravasamento de cimento. 


\section{PROPOSIÇÃO}

Avaliar comparativamente "in vitro" a capacidade seladora dos cimentos MTA branco, cinza e Sealapex consistente em obturações retrógradas, por intermédio da análise da infiltração do Enterococcus faecalis. 


\section{MATERIAL E MÉTODOS}

\subsection{Material}

\subsubsection{Dentes}

Foram utilizados oitenta dentes humanos uniradiculares extraídos, oriundos do arquivo de dentes da Disciplina de Endodontia da Faculdade de Odontologia de Bauru. Esses dentes estavam estocados em solução de formalina a $10 \%$.

\subsubsection{Cimentos utilizados}

\subsubsection{Cimento MTA Angelus ${ }^{\circledR}$ cinza* e branco**}

Todas as informações expressas aqui foram retiradas das bulas que acompanham os produtos.

O fabricante não apresenta na bula nenhuma diferença entre os dois tipos de cimentos, teoricamente tratandose do mesmo produto. Segundo o responsável técnico designado pela empresa para o atendimento aos clientes, a única diferença existente entre os dois cimentos seria a maior quantidade de óxido férrico presente no MTA cinza (Figura 1) do que no MTA branco (Figura 2)***.

\footnotetext{
${ }^{*}$ MTA Angelus - Angelus - Indústria de produtos odontológicos Ltda.

** MTA Branco - Angelus - Indústria de produtos odontológicos Ltda. *** Comunicação pessoal.
} 
A embalagem do material é composta por um vidro contendo dois gramas de pó e um frasco contendo três mililitros de água destilada. A sua fórmula apresenta a seguinte composição:

Pó: Dióxido de silício, Óxido de potássio, Alumina, Óxido de sódio, Óxido férrico, Trióxido de enxofre, Óxido de cálcio, Óxido de bismuto, Óxido de magnésio e resíduos insolúveis (sílica cristalina, sulfato de potássio e sulfato de sódio).

Líquido: Água destilada.

A proporção utilizada nos experimentos foi a recomendada pelo fabricante, uma medida de pó (utilizou-se a colher dosadora que acompanha o produto) para uma gota de água destilada.

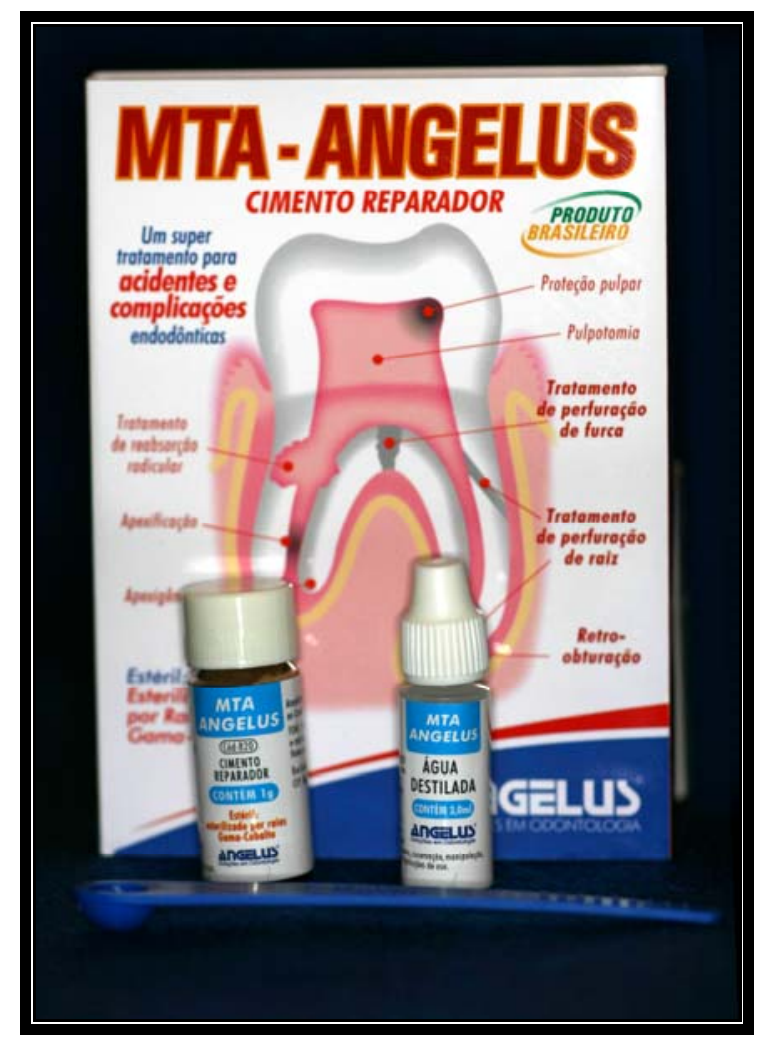

Figura 1 - Cimento MTA Angelus cinza 


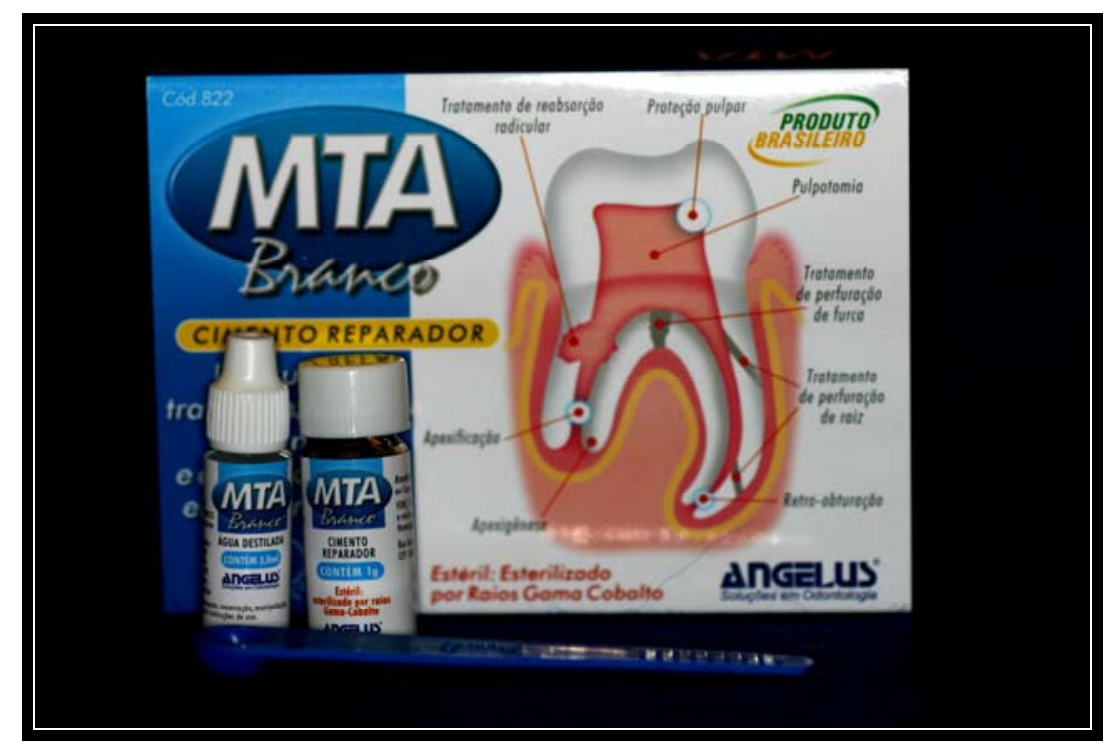

Figura 2 - Cimento MTA Angelus Branco

\subsubsection{Sealapex consistente}

O Sealapex consistente é formado pela adição de óxido de zinco (figura 4) ao cimento Sealapex (Figura 3). A incorporação do óxido de zinco ao cimento endodôntico é feita aos poucos e é realizada até que o cimento adquira a consistência de "massa de vidraceiro".

\subsubsection{Sealapex}

O cimento Sealapex* é composto por uma pasta catalisadora e uma base.

No momento do preparo do cimento, porções de base e catalisador, iguais em comprimento, devem ser misturadas até que estejam totalmente homogeneizadas. A presa ocorre em

\footnotetext{
${ }^{*}$ Sealapex ${ }^{\mathrm{TM}}$ - SybronEndo Dental Specialties.
} 
aproximadamente 60 minutos no canal radicular a $37^{\circ} \mathrm{C}$ e umidade relativa de $100 \%$.

A sua fórmula apresenta a seguinte composição:

Óxido de cálcio, Trióxido de bismuto, Óxido de zinco, Sílica sub-micro, dióxido de titânio, estereato de zinco, fosfato tricálcio, sulfonamida de tolueno etil, resina poli, salicilato de isobutil e um pigmento.

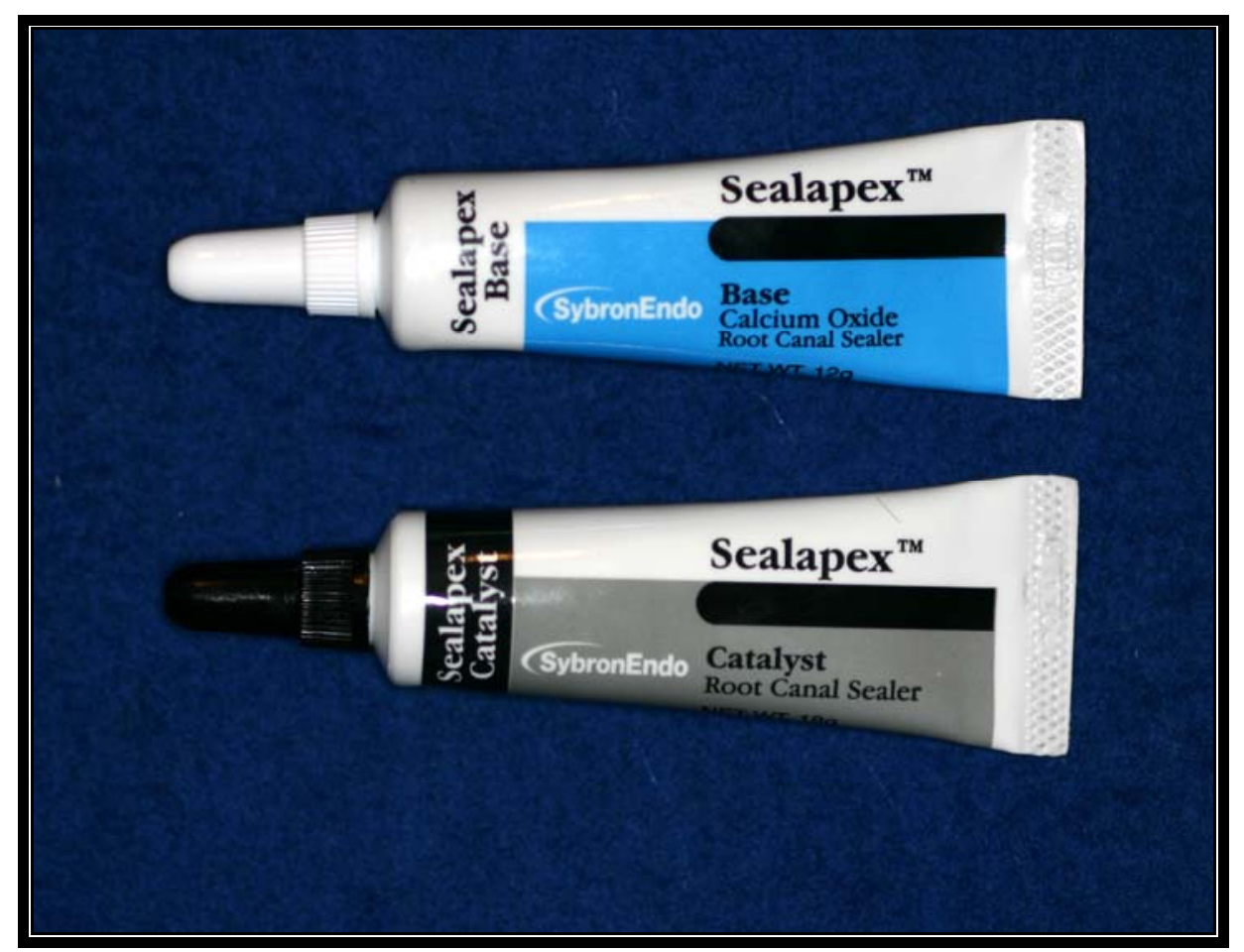

Figura 3 - Cimento Sealapex

\subsubsection{4 Óxido de Zinco}

Segundo a bula que acompanha o produto, o óxido de zinco* apresenta-se puro.

\footnotetext{
* PROBEM - Grupo Degussa Dental.
} 


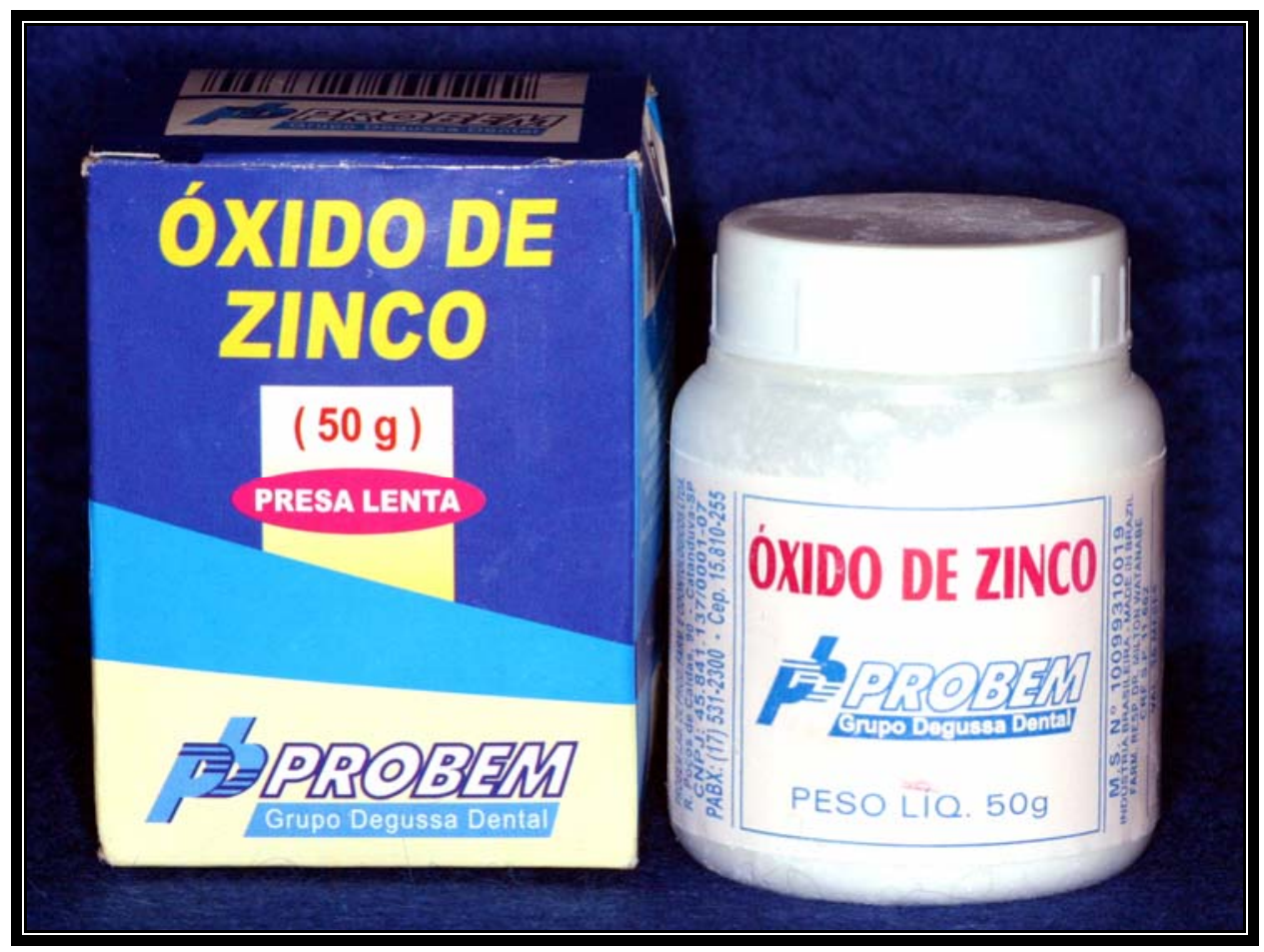

Figura 4 - Cimento de óxido de zinco

\subsubsection{Aparato experimental}

4.1.3.1 - Tubos de microcentrífuga de 1,5 mL.

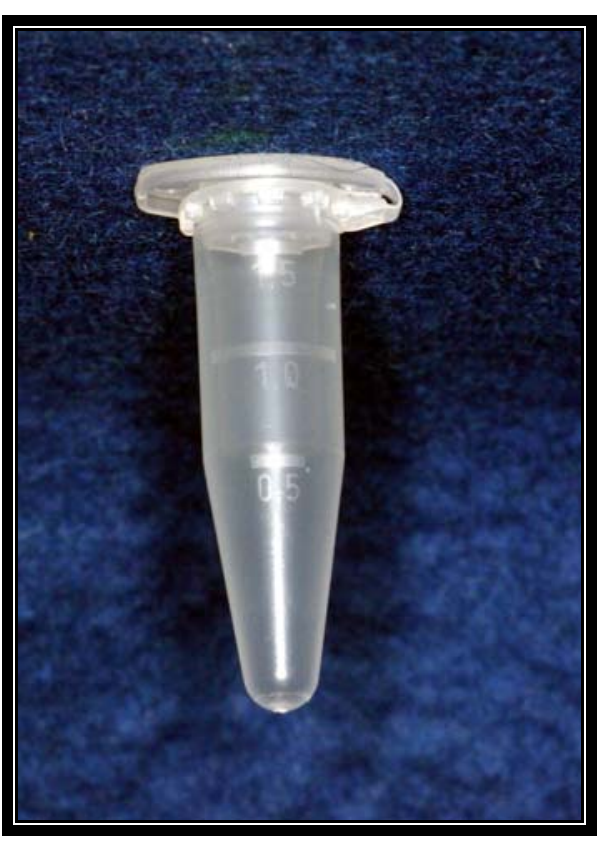

Figura 5 - Tubo de microcentrífuga de 1,5 mL 


\subsubsection{2 - Vidro tipo penicilina.}

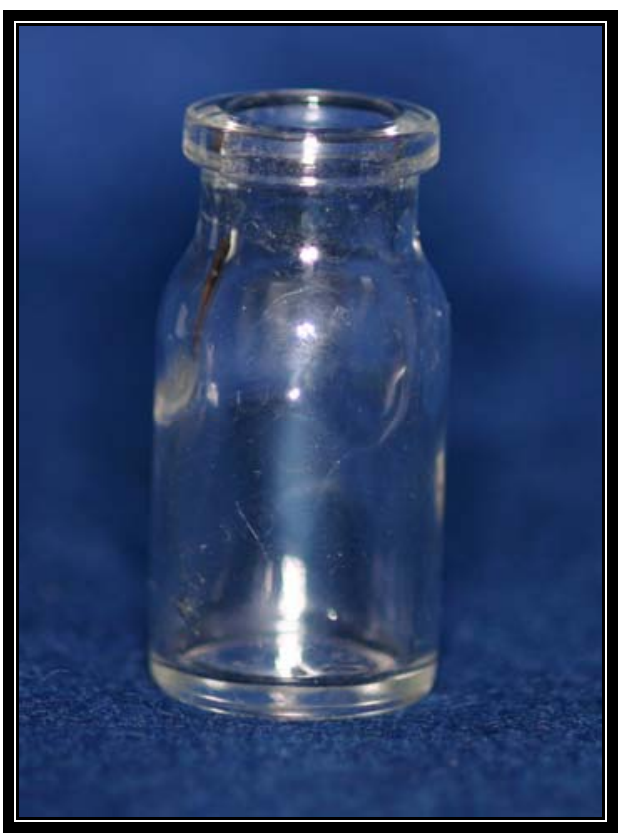

Figura 6 - Vidro tipo penicilina

\subsubsection{Meio de cultura}

O meio de cultura utilizado nesse trabalho foi Brain Heart Infusion $-\mathrm{BHI}^{*}$.

\subsubsection{Cepa}

A bactéria escolhida para a realização do trabalho foi o Enterococcus faecalis ATCC (American Type Culture Collection) 29212, uma bactéria Gram positiva, facultativa, encontrada comumente em canais radiculares, que necessitam de retratamento devido às lesões refratárias.

* Acumedia Manufactures 


\subsection{MÉTODOS}

\subsubsection{Preparo dos dentes}

Para a realização do trabalho os dentes foram removidos da solução de formalina, lavados abundantemente em água corrente e estocados por um dia em soro fisiológico.

Suas coroas foram removidas à aproximadamente um milímetro abaixo (em direção ao ápice) da junção cementoesmalte, utilizando-se discos de carburundum em baixa rotação.

Para a realização da odontometria, uma lima tipo Kerr $\mathrm{n}^{\circ} \cdot 15^{*}$ foi introduzida no canal radicular até que sua guia de penetração ficasse visível no ápice radicular, e o comprimento de trabalho foi determinado subtraindo-se um milímetro do comprimento total do instrumento, medido do limitador de penetração até a sua extremidade.

O preparo químico-mecânico do canal radicular foi realizado inicialmente com brocas Gates-Glidden* número dois e três penetrando, no máximo, dois terços do comprimento de trabalho, e os canais radiculares foram instrumentados, utilizando-se a técnica coroa-ápice, até que uma lima tipo Kerr $\mathrm{n}^{\circ}$. 40* atingisse o comprimento de trabalho. Após o uso de cada instrumento, o canal radicular foi irrigado com $1.8 \mathrm{~mL}$ de uma solução de hipoclorito de sódio a 2,5\% recém preparada.

Depois de concluído o preparo químico-mecânico, as raízes tiveram três milímetros de seus ápices removidos com uma broca Zekrya* $n^{\circ}$. 151 em alta rotação refrigerada a água. Os cortes dos ápices foram realizados perpendiculares ao longo eixo da raiz dental, evitando-se qualquer biselamento.

${ }^{*}$ Dentsply - Maillefer. 
Após a apicectomia foi confeccionada uma retrocavidade de três milímetros de profundidade por aproximadamente um milímetro de diâmetro com uma broca Carbide* $\mathrm{n}^{0} .1792$ em alta rotação refrigerada a água. Todas as raízes preparadas eram imediatamente recolocadas em soro fisiológico até o momento de sua utilização.

\subsubsection{Preparo dos grupos experimentais.}

As raízes foram distribuídas aleatoriamente em três grupos experimentais de 20 espécimes de acordo com os cimentos testados e em dois grupos controles com 10 raízes cada.

Os grupos ficaram divididos do seguinte modo:

Grupo I: MTA cinza.

Grupo II: MTA branco (Figura 7B).

Grupo III: Sealapex consistente (Figura 7A).

Grupo IV: Grupo controle negativo: as retrocavidades foram totalmente recobertas por Araldite (FIGURA 7D).

Grupo V: Grupo controle positivo: as retrocavidades foram deixadas vazias (Figura 7C).

Os cimentos MTA branco e cinza foram preparados de acordo com as recomendações do fabricante, já o cimento Sealapex foi inicialmente espatulado de acordo com as recomendações do fabricante, e em seguida acrescentou-se óxido de zinco até que se atingisse a consistência de "massa de vidraceiro" (4 gramas de Sealapex para 5 gramas de óxido de zinco). Os cimentos foram imediatamente levados as retrocavidades com curetas de dentina e condensados com

\footnotetext{
* KG Sorensen indústria e comércio Ltda.
} 
calcadores do Kit Bernabé*. Para impedir que o material retrobturador ultrapassasse o comprimento total da retrocavidade, foi colocado um cone de guta-percha que se ajustasse na luz do canal radicular três milímetros aquém da superfície apicectomizada.

A superfície radicular foi impermeabilizada com Araldite $^{* *}$ com exceção do local onde foi confeccionada a retrocavidade.

\footnotetext{
* Suplen - Indústria e comércio Ltda.

** Adesivo epóxi - Ciba especialidades químicas Ltda.
} 


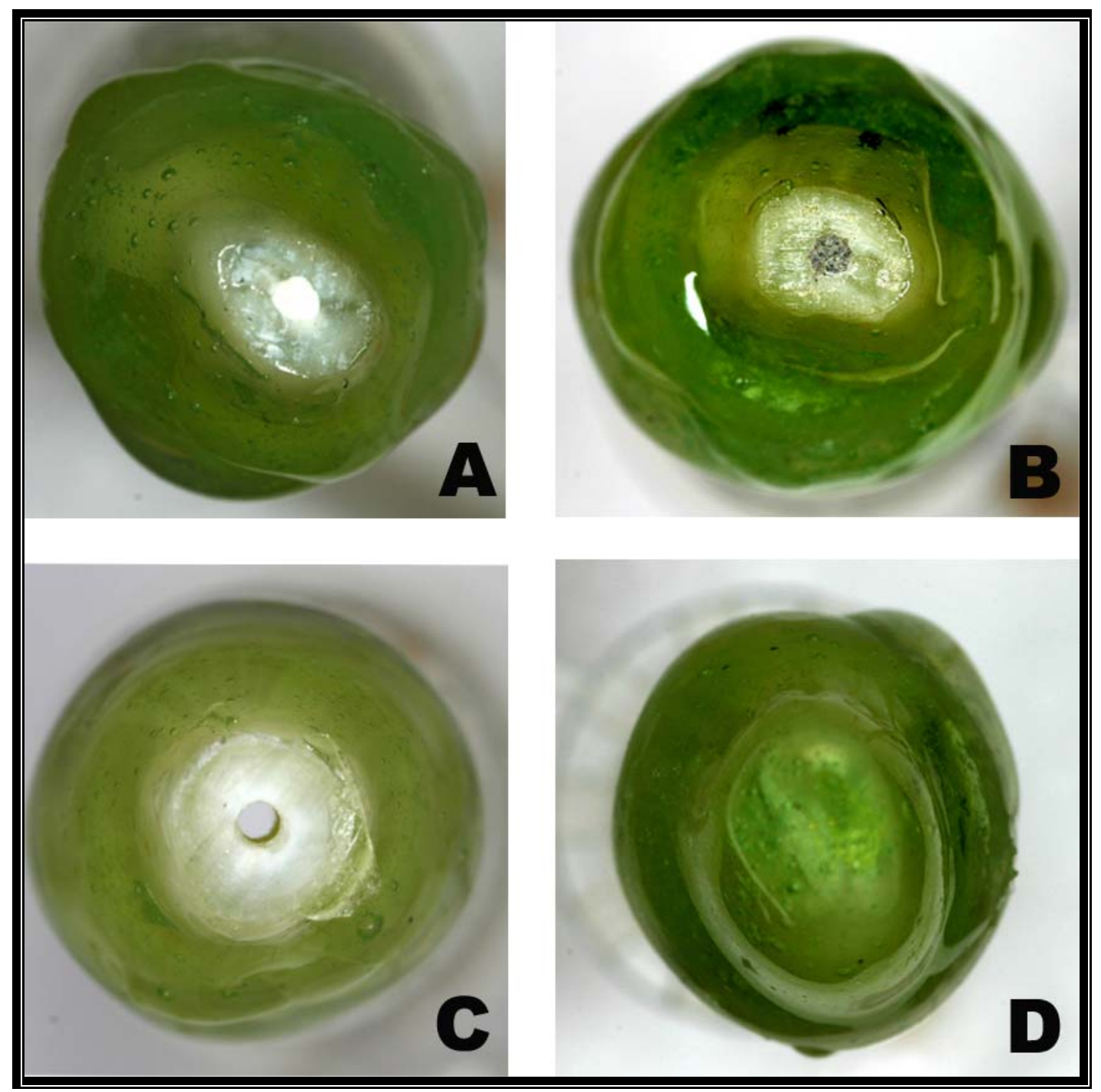

Figura 7 - (A) Raiz dental retrobturada com Sealapex consistente; (B) Raiz dental retrobturada com MTA; (C) Grupo controle positivo; (D) Grupo controle negativo.

\subsubsection{Preparo do aparato experimental}

Tubos de microcentrífuga de 1,5 mililitros foram cortados em uma das extremidades (Figura 8-A) e a raiz foi inserida até que o ápice ficasse localizado externamente (Figura 8-B). O espaço existente entre a superfície radicular e o tubo de microcentrífuga foi selado com Araldite, esse selamento proporcionou o vedamento da porção inferior do tubo de 
microcentrífuga e a união deste com a raiz dental. Depois de montados, os conjuntos constituídos pela raiz e o tubo de microcentrífuga permaneceram por 24 horas em umidificador para que todos os cimentos tomassem presa. Após esse período, os conjuntos foram embalados individualmente e submetidos ao processo de esterilização por óxido de etileno (Sterileno) a uma temperatura de $56^{\circ} \mathrm{C}$ por quatro horas.
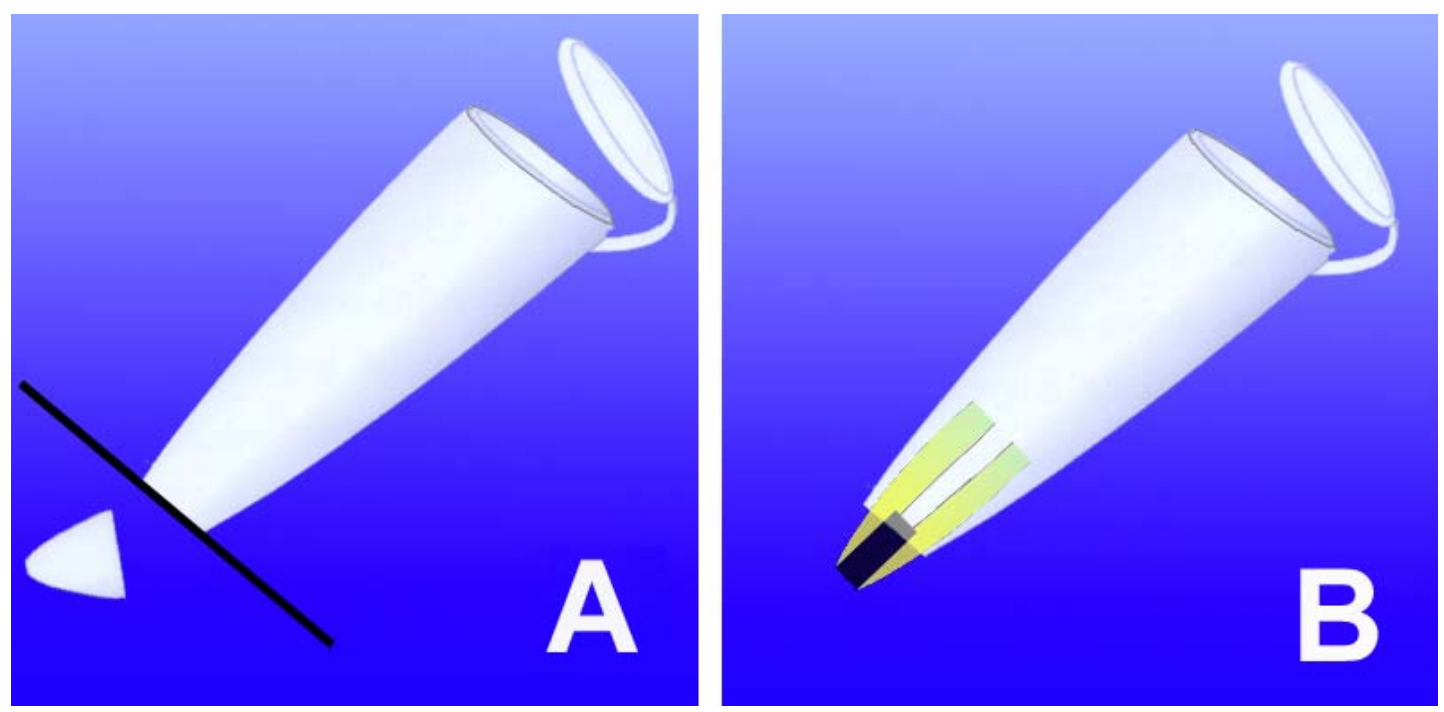

Figura 8 - Esquema da montagem da raiz dental no tubo de microcentrífuga: (A) Corte do tubo; (B) Inserção da raiz dental

Todos os procedimentos seguintes foram realizados em câmara de fluxo laminar (Figura 9). 


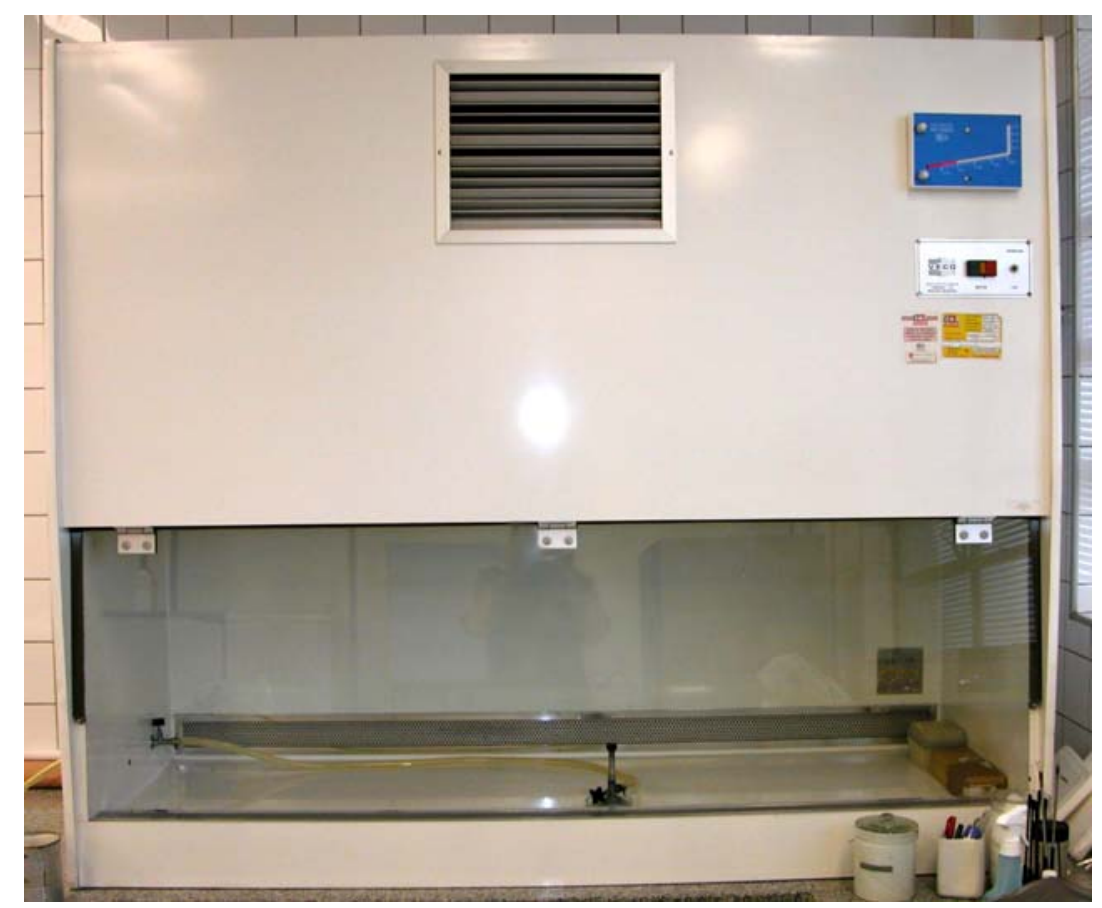

Figura 9 - Câmera de fluxo laminar

Em frascos de vidro do tipo penicilina, contendo cinco mililitros de caldo "Brain Heart Infusion" - BHI, previamente esterilizados em autoclave a $121^{\circ} \mathrm{C}$ por 15 minutos, a fixação do conjunto (raiz retrobturada colada ao tubo de microcentrífuga), submetido à esterilização pelo óxido de etileno, foi obtida pelo preenchimento entre a borda do frasco de penicilina e do tubo de microcentrífuga com Araldite (Figura 10). Nos frascos em que se detectaram falhas dessa vedação, foi colocada nova camada de Araldite para eliminar uma possível comunicação com o meio externo e esse aparato experimental (composto por frasco de vidro, caldo de BHI estéril, raiz dental e tubo de microcentrífuga). Todos os aparatos foram mantidos em estufa a $37^{\circ} \mathrm{C}$ por dois dias. Esse procedimento foi realizado para verificarmos a esterilidade de todo o aparato experimental devido à possibilidade de contaminação no momento da montagem deste dispositivo, sendo constatada qualquer turvação no caldo BHI (Figura 12), o aparato era descartado. 


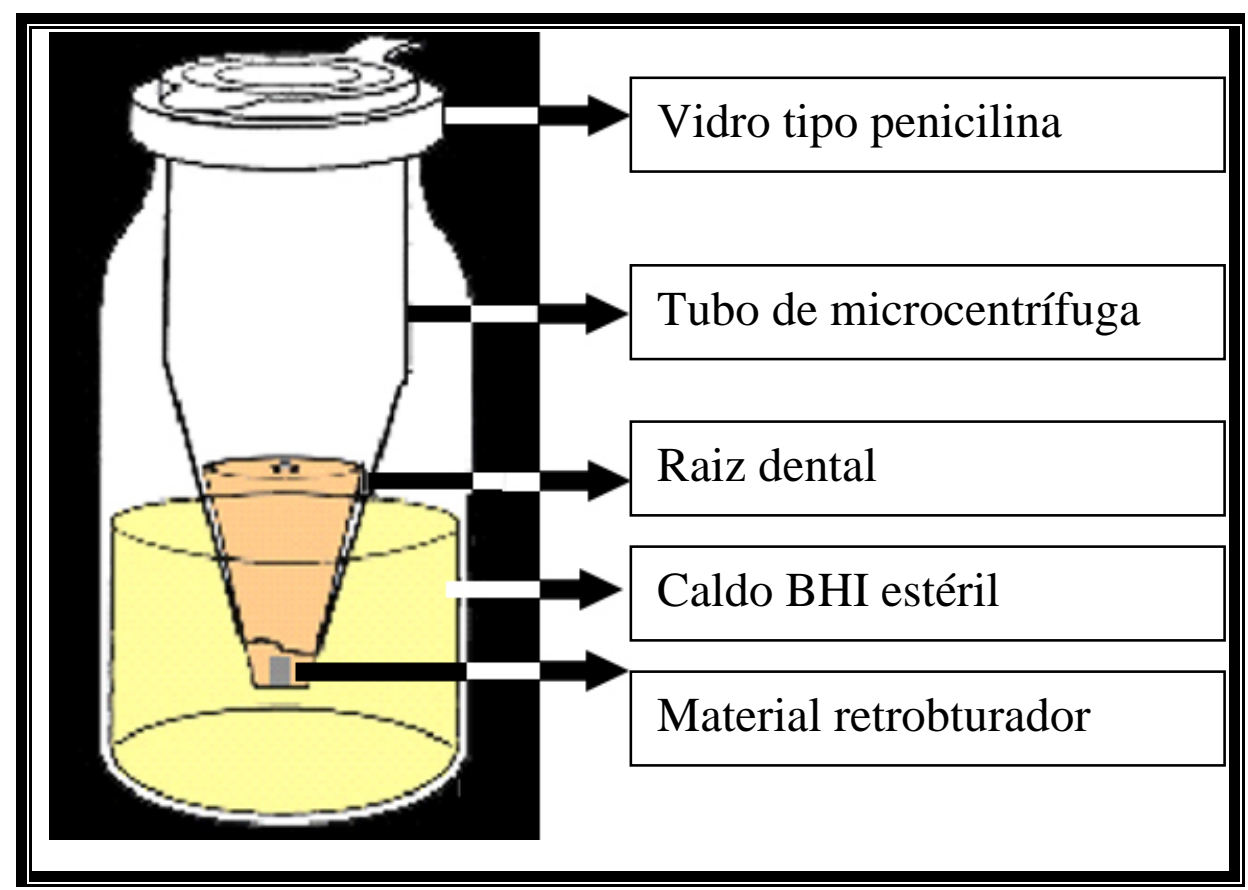

Figura 10 - Esquema do aparato experimental

Todos os aparatos foram numerados de acordo com o grupo experimental ao qual pertenciam.

\subsubsection{Preparo do inóculo}

A cepa de Enterococcus faecalis foi descongelada e reativada em tubos pyrex de $13 \times 100 \mathrm{~mm}$, com tampa de rosca, contendo cinco mililitros do caldo $\mathrm{BHI}$, sendo incubada a $37^{\circ} \mathrm{C}$ por 24 horas. Após ser constatada a viabilidade da cepa, foi verificada a morfologia colonial em placas de Petri contendo 20,0 mL de Ágar Sangue* (AS) e Ágar Mitis Salivarius * (MSA), seguido pela confirmação da morfologia celular pelo método da coloração de Gram. Ambos os procedimentos foram realizados para confirmar a pureza da cepa.

\footnotetext{
* Acumedia Manufactures
} 
Uma colônia pura foi transferida para tubos contendo cinco mililitros de caldo $\mathrm{BHI}$ e mantida a $37^{\circ} \mathrm{C}$ por 24 horas, repetindo-se esta transferência por mais duas vezes para se obter o microrganismo em crescimento exponencial. Cem microlitros do último crescimento foram semeados em $50 \mathrm{~mL}$ de caldo $\mathrm{BHI}$ e mantidos a $37^{\mathrm{a}} \mathrm{C}$ por 18 horas. Finalmente alíquotas de $400 \mu \mathrm{L}$ desta última amostra foram transferidas para o interior dos tubos de microcentrífuga e o aparato foi mantido em estufa a $37^{\circ} \mathrm{C}$ durante todo o experimento (Figura 11).

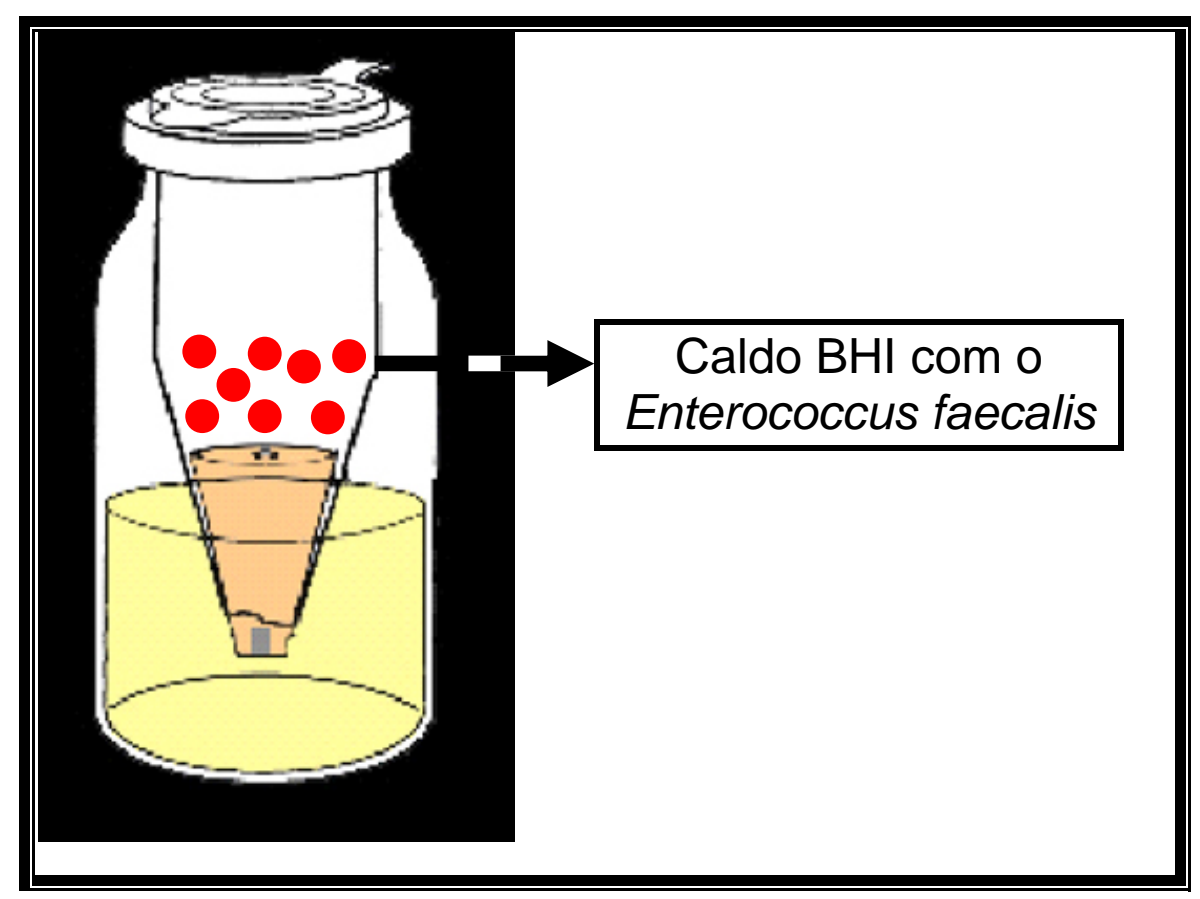

Figura 11 - Aparato após a inserção do Enterococcus faecalis

\subsubsection{Obtenção dos resultados}

Os aparatos foram checados diariamente para verificação da turvação do meio (Figura 12), que foi o indicativo da passagem das bactérias pelo material retrobturador. O aparato que apresentasse o meio em seu interior turvo era retirado da estufa e seu número era anotado. 
Semanalmente o caldo $\mathrm{BHI}$ do interior do tubo de microcentrífuga era renovado para permitir que as bactérias continuassem a reproduzir-se e manterem-se viáveis.

Quinzenalmente era realizado o "teste de viabilidade das bactérias", que consistia em transferir o caldo BHI, proveniente do interior dos tubos de microcentrífuga, para tubos de ensaio com caldo BHI estéril e depois de incubados por 48 horas, a $37^{\circ} \mathrm{C}$, verificar se ocorreria turvação do meio.

O tempo máximo de observação das amostras foi de 120 dias.

Na figura 12 observamos a turvação existente no meio do aparato B a qual indica que o microrganismo infiltrou-se pelo cimento e chegou ao caldo, multiplicando-se neste.

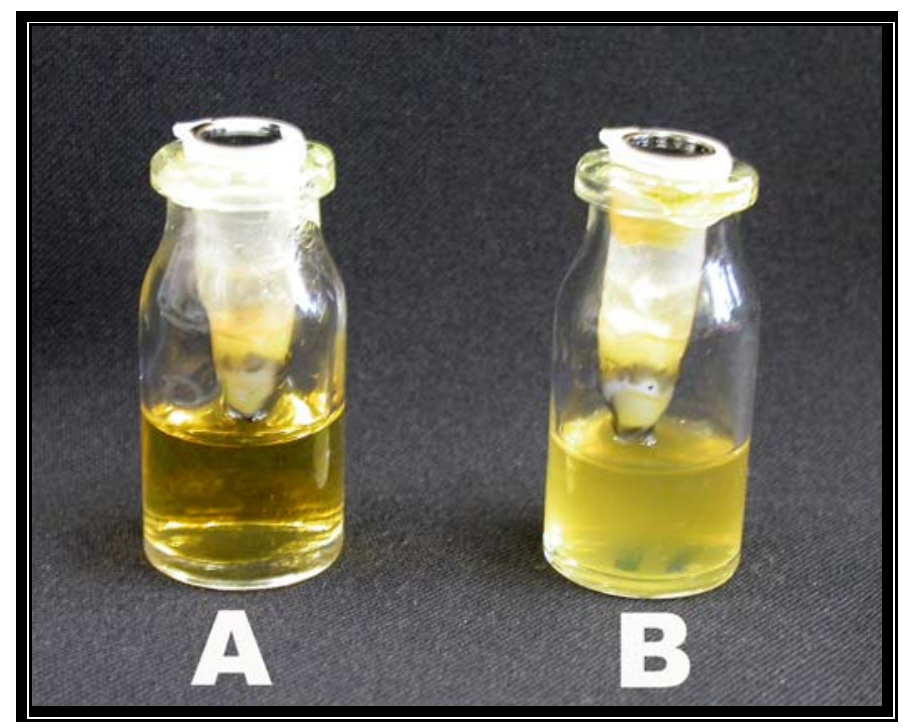

Figura 12 - (A) Aparato sem turvação; (B) Aparato com turvação.

Foi utilizado o teste Qui-Quadrado para a verificação da existência ou não de diferença de infiltração ocorrida entre os diferentes grupos experimentais. 


\section{RESULTADOS}

Os três grupos experimentais apresentaram espécimes com infiltração bacteriana que foram aumentando numericamente no decorrer do período experimental, enquanto que nenhum espécime do grupo controle negativo apresentou infiltração, o que comprova a qualidade da impermeabilização externa da raiz dental. Todos os espécimes do grupo controle positivo apresentaram turvação em 24 horas, demonstrando a confiabilidade do aparato desenvolvido para 0 teste de infiltração bacteriana.

Apesar do acompanhamento das amostras ter sido realizado diariamente, a tabela 1 mostra o número de espécimes com infiltração a cada período de 30 dias. Esse período foi escolhido para facilitar a visualização do comportamento dos grupos experimentais durante a pesquisa. Os resultados das observações diárias podem ser conferidos no Anexo A. 
Tabela 1 - Número de espécimes que sofreram infiltração a cada período de 30 dias.

\begin{tabular}{|l|c|c|c|c|c|}
\hline & 30 dias & 60 dias & 90 dias & 120 dias & TOTAL \\
\hline MTA cinza & 2 & 2 & 5 & 2 & $\mathbf{1 1}$ \\
\hline MTA branco & 1 & 2 & 3 & 3 & $\mathbf{9}$ \\
\hline Sealapex consistente & 1 & 3 & 3 & 3 & $\mathbf{1 0}$ \\
\hline Controle negativo & 0 & 0 & 0 & 0 & $\mathbf{0}$ \\
\hline Controle positivo & 10 & 10 & 10 & 10 & $\mathbf{1 0}$ \\
\hline
\end{tabular}


O gráfico 1 representa o numero de amostras infiltradas no decorrer do período experimental, demonstrando que os cimentos, além do resultado final semelhante, tiveram um comportamento muito próximo durante todo período experimental.

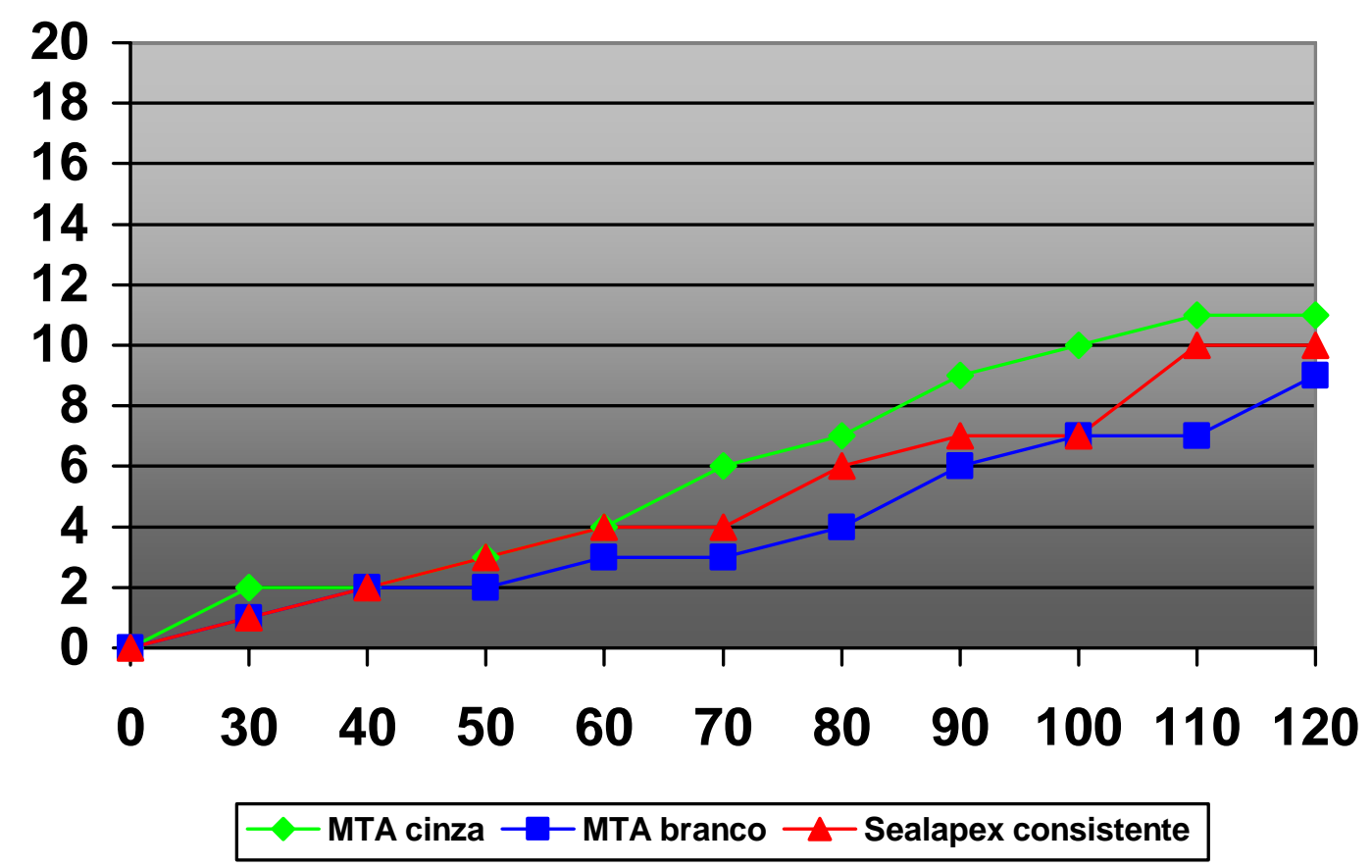

Gráfico 1 - Representação gráfica do número de amostras que infiltraram em função do tempo ( $y=$ amostras com infiltração e $x=$ dias $)$

O gráfico 2 indica o número de amostras dos cimentos testados com infiltração ao final do período experimental. 


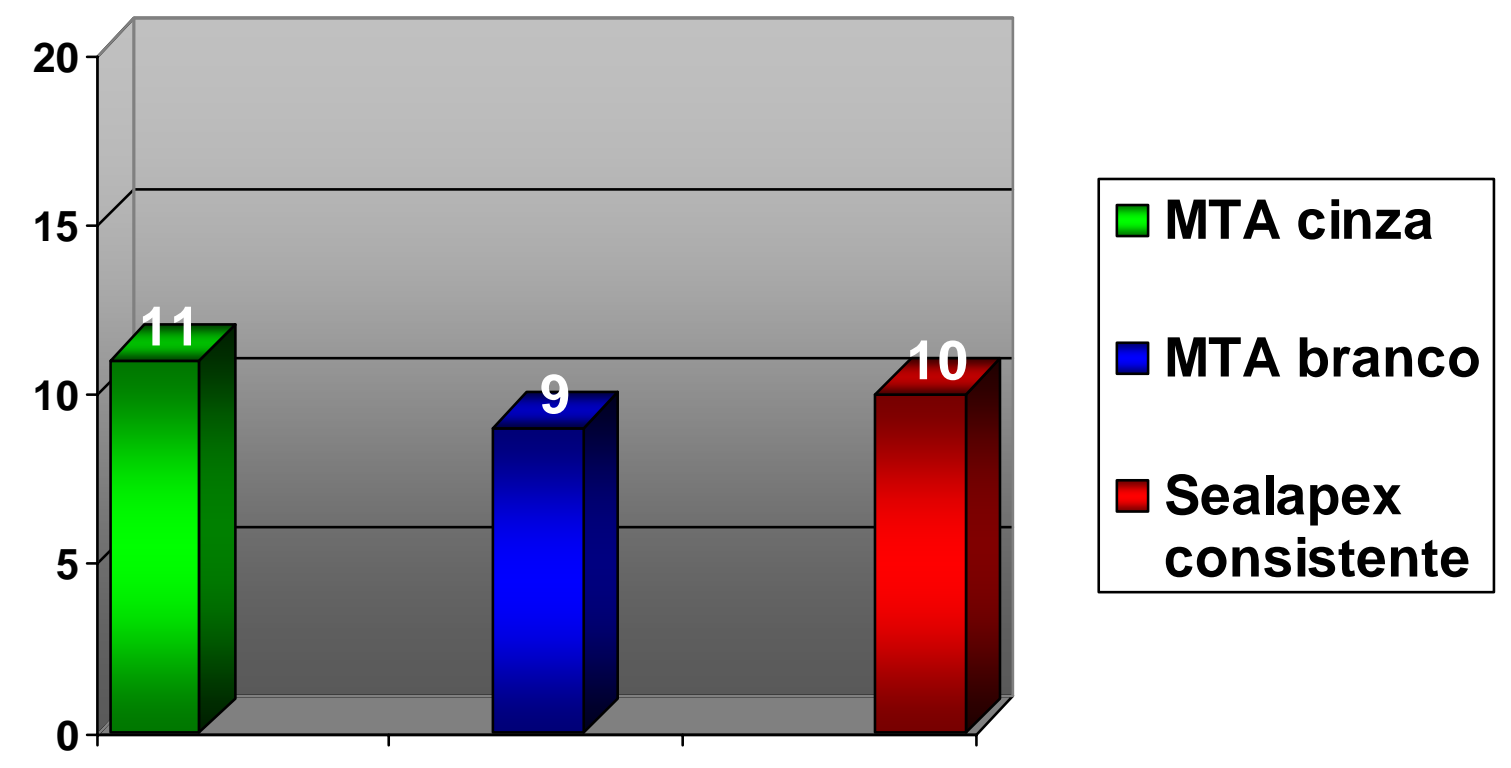

Gráfico 2 - Espécimes com infiltração após 120 dias.

O teste de QUI-QUADRADO mostrou não haver diferença estatisticamente significante entre a quantidade de espécimes infiltrados nos cimentos testados $\left(x^{2}=0,40\right.$ $p=0,819)$. 


\section{DISCUSSÃO}

A cirurgia parendodôntica, dentro de suas modalidades, está indicada quando o retratamento endodôntico falha ou é contra-indicado. E dentro dessas modalidades cirúrgicas a obturação retrógrada envolve uma grande variedade de materiais, mas a procura pelo material ideal continua intensa. Esse material deve apresentar boas propriedades físicas sem deixar de lado as propriedades biológicas. A capacidade de selamento e adaptação marginal são importantes (HARTY et al. ${ }^{38}$, TORABINEJAD et al. ${ }^{85}$, TORABINEJAD; WATSON; PITT FORD $^{81}$, TORABINEJAD et al. ${ }^{82}$, LUIZ ${ }^{52}$, BERNABÉ; HOLLAND ${ }^{13}$ ), pois, tem influência direta no prognóstico das cirurgias parendodônticas, inibindo a passagem de bactérias e de seus produtos tóxicos para os tecidos periapicais, bem como do líquido intersticial para o canal radicular.

A capacidade de selamento de alguns cimentos, indicados para a obturação retrógrada, como o MTA cinza, o MTA branco e o Sealapex consistente, deve ser avaliada considerando que os mesmos possuem capacidade indutora de mineralização, já conhecida (TORABINEJAD et al. ${ }^{87}$, MORANDI ${ }^{60}$, LUIZ ${ }^{5}$, LEONARDO ${ }^{51}$, TAGGER;TAGGER ${ }^{76}$ 1989, TANOMARU FILHO et al. ${ }^{79}$ ). 


\section{1 - DISCUSSÃO DA METODOLOGIA}

\subsection{1 - Técnica de infiltração}

Várias técnicas de estudos "in vitro" têm sido utilizadas para avaliar a capacidade seladora dos diferentes materiais retrobturadores. Os resultados desses estudos são contraditórios, pois são dependentes do tipo de infiltração utilizado. Os estudos envolvendo técnicas de infiltração de corantes são comumente utilizados devido a sua facilidade de acompanhamento, rapidez e por não exigirem equipamentos sofisticados para sua realização, porém seus resultados são questionáveis (TORABINEJAD ${ }^{0}$ et al. ${ }^{83}$ 1995, TORABINEJAD, WATSON; PITT FORD ${ }^{81}$ 1990, TANG et al. 78 2002, WU; WESSELINK ${ }^{93}$ 1994, POMMEL et al. 64 2003, CAMPS; PASHLEY ${ }^{16} 2003$ ).

Segundo AL-GHAMDI; WENNENBERG ${ }^{3}$ (1994) não existe norma que especifique procedimentos estandardizados para testes de infiltração, sendo o uso de corantes, como marcador de infiltração, a técnica mais antiga, simples e popular. Entretanto, há uma variedade muito grande de técnicas e metodologias, o que torna muito difícil uma padronização.

Inúmeros autores descreveram limitações existentes nas técnicas de penetração de corantes; segundo ADAMO et al. ${ }^{1}$ (1995) as partículas do corante são menores que as bactérias e, por esse motivo, estudos que utilizam corantes tendem a ter valores de infiltração maiores que aqueles que se utilizam de bactérias. MAGURA et al. ${ }^{53}$ (1991) avaliaram a penetração de bactérias e de corantes em dentes tratados endodonticamente e concluíram que a penetração bacteriana é menor que a do corante e afirmaram que técnicas de infiltração de corantes subestimam a capacidade seladora dos materiais testados. 
Mesmo quando se compara diferentes técnicas que utilizam corantes, os resultados são contraditórios. WU; DE GEE; WESSELINK ${ }^{94}$ (1994), POMMEL et al. 64 (2003), e CAMPS;PASHLEY ${ }^{16}$ (2003) não encontraram correlação entre os resultados de diferentes técnicas de infiltração de corante. DELIVANIS; TABIBI ${ }^{22}$ (1978), CHAPMAN et al. $^{19}$ (1990) encontraram pobre correlação entre as técnicas de penetração de corante e de radioisótopos; e MATLOFF et al. ${ }^{55}$ (1982) não encontraram nenhuma correlação entre as duas técnicas anteriormente citadas. Os mesmos autores ainda afirmaram que estudos realizados com radioisótopos não são confiáveis para testar a capacidade seladora de cimentos, porque as partículas dos radioisótopos, como as partículas de corantes, são menores que bactérias. A comparação dos resultados de infiltração bacteriana e de corante nos mesmos dentes não demonstrou relação entre os dois métodos (SWITZER; MOSHONOV; TROPE $^{75}$ 1996). Outros autores como BARTHEL et al. ${ }^{10}$ (1999), KERSTEN; MOORER ${ }^{45}$ (1989) também não encontraram nenhuma correlação entre as técnicas de infiltração de corante e infiltração bacteriana. Segundo TORABINEJAD et al. ${ }^{83}$ (1995) e TANG et al. $^{78}$ (2002) existe uma inadequação entre as técnicas de penetração de corante, radioisótopo e bacteriana e que essa última seria a mais recomendada para a realização de testes de infiltração.

Cada um desses métodos possui vantagens e desvantagens, porém em vista do exposto anteriormente, concordamos com MORTENSEN (1965) et $\mathbf{a l}^{61}$. , KRAKOW; DE STOPPELAAR; GRON ${ }^{47}$ (1977), TORABINEJAD (1995)et al. ${ }^{83}$, SILVA E SOUZA ${ }^{71}$ (2004) e TORABINEJAD; UNG; KETTERING $^{80}$ (1990) os quais afirmam que bactérias são mais apropriadas que corantes e radioisótopos para a realização de 
estudos de avaliação da capacidade seladora dos materiais retrobturadores.

\subsection{2 - Escolha do material retrobturador}

A escolha correta do material retrobturador é de fundamental importância para o sucesso da cirurgia parendodôntica, tal material além de possuir boa capacidade seladora deve ser biologicamente compatível, caso contrário, a despeito de sua capacidade seladora, poderá gerar uma série de eventos patológicos desfavoráveis que poderão levar ao insucesso do tratamento (BERNABÉ et al. ${ }^{13} 2004$, LUIZ $^{52} 2003$, FARACO JÚNIOR ${ }^{28}$ 1999). O MTA tem sido indicado como um cimento para selamento de comunicações entre a cavidade pulpar e o ligamento periodontal (TORABINEJAD et al. ${ }^{87}$ 1995, MORANDI ${ }^{60}$ 1999, FARACO JUNIOR ${ }^{28} 1999$, FARACO JUNIOR; HOLLAND ${ }^{29}$ 2001).

Os primeiros autores a publicarem sobre o MTA foram LEE; MONSEF; TORABINEJAD ${ }^{48}$ (1993), e nessa última década, muito mais foi publicado a respeito desse cimento e a grande maioria desses artigos ressalta suas excelentes propriedades físicas e biológicas, indicando-o como o material de primeira escolha para a utilização em retrobturações. Segundo TORABINEJAD; CHIVIAN $^{88}$ (1999), além de sua utilização em retrobturações, o MTA pode ser indicado em perfurações radiculares, capeamento pulpar direto, pulpotomias, como tampão apical para o selamento de dentes com rizogênse e como tampão cervical previamente aos procedimentos de clareação interna. Além disso, vários estudos têm demonstrado sua biocompatibilidade (TORABINEJAD et al. ${ }^{87} 1995$, MORANDI $^{60}$ 1999, FARACO JUNIOR ${ }^{28}$ 1999, MENEZES ${ }^{56} 2004$, 
BERNABÉ et al. ${ }^{12}$ 2002, ROCHA ${ }^{66}$ 2003) e sua excelente capacidade seladora (LEE ; MONSEF; TORABINEJAD ${ }^{48} 1993$, TORABINEJAD et al. ${ }^{81}$ em 1993, TORABINEJAD et al. ${ }^{82} 1994$, AQRABAWI $^{2}$ 2000, HOLLAND et al. ${ }^{41}$ 2001, ROCHA ${ }^{66}$ 2003).

O MTA é apresentado em pó composto de partículas hidrofílicas, que endurece em presença de umidade. A hidratação desse pó resulta em uma massa fluída, com pH de 12,5 que ao tomar presa resulta em uma estrutura dura. No entanto, essa massa fluída resultante da manipulação do pó é de difícil aplicação, dificultando o preenchimento de uma cavidade retrógrada.

Sobre o cimento Sealapex inúmeros trabalhos têm demonstrado que ele produz um selamento marginal superior aos cimentos à base de óxido de zinco e eugenol e aos cimentos resinosos (HOLLAND et al. ${ }^{41}$ 1991, HOLLAND et al. ${ }^{42}$ 1996), além de possuir excelentes propriedades biológicas (BERNABÉ et al. ${ }^{13}$ 2004, HOLLAND; SOUZA ${ }^{40}$ 1985, LUIZ ${ }^{52}$ 2003). Todavia, para a utilização do Sealapex como material retrobturador BERNABÉ et al. ${ }^{13}(2004) ;$ LUIZ $^{52}$ (2003) recomendam que o cimento Sealapex seja modificado quando comparado ao seu uso na obturação de canais radiculares, para tanto é acrescentado óxido de zinco ao cimento, até que essa mistura atinja a consistência de "massa de vidraceiro". Considerando a facilidade de manipulação e preenchimento, o Sealapex acrescido de óxido de zinco apresentou grande vantagem com relação ao MTA, uma vez que a consistência do mesmo facilitou a introdução nas retrocavidades. 


\subsection{3 - Aparato experimental}

Foram utilizados dentes humanos uniradiculares extraídos, tanto superiores quanto inferiores com exceção dos incisivos inferiores, que foram excluídos, devido ao reduzido diâmetro de seu canal radicular.

Durante todo o experimento, procuramos manter os dentes em ambiente úmido e a temperatura de $37^{\circ} \mathrm{C}$, para se evitar trincas por desidratação.

As coroas foram removidas abaixo da junção cemento-esmalte (CAMPS; PASHLEY ${ }^{16}$ 2003, POMMEL et al. ${ }^{64}$ 2003, CANALDA-SAHLI et al. ${ }^{18}$ 1992, SILVA NETO et al. ${ }^{70}$ 2003), para facilitar a instrumentação do canal radicular, bem como a passagem do meio de cultura com as bactérias e seu contato com os cimentos retrobturadores. A remoção das coroas dentais também auxiliou na aproximação do tamanho das raízes.

As modalidades de cirurgias parendodônticas, envolvendo obturações retrógradas, compreendem: a obturação retrógrada propriamente dita (técnica clássica e técnica de Nicholls), retroinstrumentação com retrobturação, retroinstrumentação com retrobturação e obturação retrógrada e canalização. (BRAMANTE; BERBERT ${ }^{14}$ 2000)

A técnica clássica foi adotada neste trabalho pelo fato de ser amplamente conhecida e indicada. WADA et al. ${ }^{92}$ (1998) justificaram a realização da apicectomia, observando que $70 \%$ dos dentes que apresentaram lesões refratárias ao tratamento endodôntico possuíam ramificações apicais.

Quanto ao nível das ressecções radiculares KIM et al. ${ }^{46}$ (1997) demonstraram que realizadas a um milímetro do ápice radicular reduzem em $52 \%$ das ramificações e $40 \%$ dos canais laterais, a dois milímetros ocorre redução desses eventos em $78 \%$ e $86 \%$ respectivamente e quando a apicectomia é realizada a três milímetros do ápice radicular evidencia-se uma 
redução dos canais laterais da ordem de $93 \%$ e das ramificações em torno de $98 \%$, por esse motivo optamos em remover os três milímetros apicais.

O seccionamento radicular foi perpendicular ao longo eixo da raiz (corte horizontal), tal decisão foi tomada embasada no trabalho de GILHEANY; FIGDOR; TYAS ${ }^{33}$ (1994), o qual demonstrou que o corte biselado da raiz contribui significativamente para o aumento dos índices de infiltração marginal. Outra observação importante dos autores é que quanto mais biselada for a superfície apicectomizada, mais profunda deve ser a retrobturação.

Neste tipo de experimento "in vitro", a impermeabilização externa das raízes é de fundamental importância, pois previne a passagem de bactérias pelas paredes laterais ou canais laterais, o que foi salientada por TORABINEJAD et al. ${ }^{83}$ (1995). No nosso trabalho utilizou-se Araldite, a exemplo de outros trabalhos (SIQUEIRA et al. ${ }^{72} 2004$, HOLLAND et al. ${ }^{41}$ 1991, BERNABÉ et al. ${ }^{12}$ 2002). Essa técnica de impermeabilização mostrou-se bastante eficiente visto que os controles negativos não apresentaram nenhuma infiltração bacteriana.

A seguir, as raízes foram montadas em tubos de microcentrífuga e o conjunto foi levado à esterilização em gás de óxido de etileno. É importante discutir que, nesse momento, os espécimes foram submetidos a um tratamento diferente ao adotado clinicamente, pois as condições de umidade e temperatura foram alteradas. Para minimizar esse efeito, procurou-se realizar esse procedimento no tempo mais rápido possível. Apesar do método de esterilização empregado ter sido utilizado em estudos similares ao nosso (ADAMO et al. ${ }^{1}$ 1999, SILVA E SOUZA ${ }^{71}$ 2004, SIQUEIRA et al. ${ }^{72}$ 2004), não encontramos na literatura trabalhos que avaliem 0 
comportamento dos materiais obturadores após esse processo de esterilização. Entretanto, acreditamos que esse aspecto não interferiu na comparação entre os grupos, visto que todos foram submetidos às mesmas condições experimentais, porém, devese ter cautela na interpretação desses dados como orientação do comportamento clínico dos cimentos testados.

O Enterococcus faecalis foi a bactéria escolhida para a realização desse trabalho devido a sua fácil manipulação no laboratório e também por ser uma bactéria usualmente isolada de canais infectados e de lesões refratárias ao tratamento endodôntico convencional (PINHEIRO ${ }^{63}$ 2000, GOMES ${ }^{34}$ 2002, ÇOBANKARA et al. $^{20}$ 2004, FUSS; WEISS; SHALHAV ${ }^{31}$ 1997), desse modo é de grande interesse a verificação de materiais retrobturadores que possam impedir a sua infiltração.

O período experimental foi de 120 dias; optamos por esse período devido a um trabalho piloto que desenvolvemos anteriormente o qual teve a duração aproximada de 210 dias, nesse experimento piloto observamos que após os 120 dias iniciais ocorreu um decréscimo bastante acentuado no número de amostras que infiltraram, chegando mesmo a existir grupos experimentais nos quais não ocorreu infiltração. Diferentemente das nossas observações MAGURA et al. ${ }^{53}$, HAÏKEL et al. ${ }^{37}$ afirmam que quanto maior o período que as amostras ficam expostas ao material utilizado para a verificação da infiltração, maior será o número de espécimes infiltrados.

\section{2 - Discussão dos resultados}

Durante todo o decorrer do período experimental, observamos que os cimentos MTA cinza, branco e Sealapex consistente tiveram comportamento semelhante (Gráfico 1). O 
teste de QUI-Quadrado $\left(x^{2}=0,40\right)$ mostrou que não existiu diferença significante $(p=0,819)$ entre os materiais testados. Corroborando com os resultados deste trabalho, TSELNIK; BAUMGARTMER; MARSHALL ${ }^{90}$ (2004) não encontraram diferença entre o MTA cinza e o MTA branco frente à infiltração bacteriana e SIQUEIRA et al. ${ }^{72}$ (2004) demonstraram que o MTA Pro Root e MTA Angelus comportaram-se de maneira semelhante frente à infiltração bacteriana.

No que concerne, ainda à capacidade seladora do MTA LEE; MONSEF; TORABINEJAD ${ }^{48}$ (1993), TORABINEJAD et al. $^{82}$ (1994), AQRABAWI ${ }^{2}$ (2000) e SCHEERER; STEIMAN; COHEN $^{68}$ (2001) encontraram resultados opostos aos obtidos neste trabalho, pois, não visualizaram infiltração alguma.

A respeito do Sealapex inúmeros trabalhos na literatura têm demonstrado sua efetividade seladora comparando-o com outros cimentos à base de hidróxido de cálcio, à base de óxido de zinco e eugenol ou resinosos. BRONG et al. ${ }^{15}$ (2002) comparando-o aos cimentos Sealer 26, Endofill e Roekoseal obtiveram com o Sealapex os menores índices de infiltração. HOLLAND et al. ${ }^{41}$, em 1991, obtiveram com o Sealapex, quando comparado aos cimentos de óxido de zinco eugenol, Fill Canal, Rickert, AH26, CRCS e New B2 os menores índices de infiltração.

\section{3 - Considerações finais}

O significado clínico dos estudos de selamento marginal, relacionados com a infiltração de bactérias é ainda indefinido e não há dúvidas de que todas as metodologias existentes não são suficientes para oferecer resultados que possam ser considerados definitivos e totalmente aplicáveis na clínica, e que a extrapolação direta de resultados obtidos em 
trabalhos "in vitro" é questionável. Portanto, os resultados observados neste tipo de trabalho podem não exprimir exatamente o que acontece na intimidade dos tecidos, onde os materiais podem se comportar de maneira diferente. Porém trabalhos como este aqui apresentado, podem nos dar uma boa idéia a respeito das propriedades físicas dos cimentos testados, levando-se em conta que diferentemente dos testes de infiltração, onde se utilizam corantes, este trabalho utilizou-se de uma bactéria comumente encontrada nos canais radiculares infectados e em lesões periapicais. 


\section{CONCLUSÕES}

Considerando a metodologia empregada neste estudo e os resultados obtidos, podemos concluir que:

$\checkmark \quad$ Nenhum dos cimentos testados foi capaz de impedir a infiltração bacteriana em todos os espécimes.

$\checkmark$ Os cimentos MTA cinza o MTA branco e o Sealapex consistente mostraram possuir comportamento semelhante frente à infiltração do Enterococcus faecalis em obturações retrógradas nos períodos estudados. 


\section{ANEXO*}

Número de espécimes que sofreram infiltração, observações diárias.

\begin{tabular}{|c|c|c|c|c|c|}
\hline DIAS & MTA CINZA & MTA BRANCO & $\begin{array}{c}\text { SEALAPEX } \\
\text { CONSISTENTE }\end{array}$ & $\begin{array}{l}\text { CONTROLE } \\
\text { NEGATIVO }\end{array}$ & $\begin{array}{l}\text { CONTROLE } \\
\text { POSITIVO }\end{array}$ \\
\hline 1. & 0 & 0 & 0 & 0 & 0 \\
\hline 2. & 0 & 0 & 0 & 0 & 10 \\
\hline 3. & 0 & 0 & 0 & 0 & 0 \\
\hline 4. & 0 & 0 & 0 & 0 & 0 \\
\hline 5. & 0 & 0 & 0 & 0 & 0 \\
\hline 6. & 0 & 0 & 0 & 0 & 0 \\
\hline 7. & 0 & 0 & 0 & 0 & 0 \\
\hline 8. & 0 & 0 & 0 & 0 & 0 \\
\hline 9. & 0 & 0 & 0 & 0 & 0 \\
\hline 10. & 0 & 0 & 0 & 0 & 0 \\
\hline 11. & 0 & 0 & 0 & 0 & 0 \\
\hline 12. & 0 & 0 & 0 & 0 & 0 \\
\hline 13. & 0 & 0 & 0 & 0 & 0 \\
\hline 14. & 0 & 0 & 0 & 0 & 0 \\
\hline 15. & 0 & 0 & 0 & 0 & 0 \\
\hline 16. & 0 & 0 & 0 & 0 & 0 \\
\hline 17. & 0 & 0 & 0 & 0 & 0 \\
\hline 18. & 0 & 0 & 0 & 0 & 0 \\
\hline 19. & 0 & 0 & 0 & 0 & 0 \\
\hline 20. & 0 & 0 & 0 & 0 & 0 \\
\hline 21. & 0 & 0 & 0 & 0 & 0 \\
\hline 22. & 0 & 0 & 0 & 0 & 0 \\
\hline 23. & 1 & 1 & 0 & 0 & 0 \\
\hline 24. & 0 & 0 & 0 & 0 & 0 \\
\hline 25. & 0 & 0 & 0 & 0 & 0 \\
\hline 26. & 0 & 0 & 0 & 0 & 0 \\
\hline 27. & 0 & 0 & 0 & 0 & 0 \\
\hline 28. & 0 & 0 & 1 & 0 & 0 \\
\hline 29. & 1 & 0 & 0 & 0 & 0 \\
\hline 30. & 0 & 0 & 0 & 0 & 0 \\
\hline 31. & 0 & 0 & 0 & 0 & 0 \\
\hline 32. & 0 & 0 & 0 & 0 & 0 \\
\hline 33. & 0 & 1 & 0 & 0 & 0 \\
\hline 34. & 0 & 0 & 0 & 0 & 0 \\
\hline 35. & 0 & 0 & 0 & 0 & 0 \\
\hline
\end{tabular}

* NBR 10719 da ABNT (Associação Brasileira de Normas Técnicas) 


\begin{tabular}{|c|c|c|c|c|c|}
\hline 36. & 0 & 0 & 1 & 0 & 0 \\
\hline 3. & 0 & 0 & 0 & 0 & 0 \\
\hline 38. & 0 & 0 & 0 & 0 & 0 \\
\hline 39. & 0 & 0 & 0 & 0 & 0 \\
\hline 40. & 0 & 0 & 0 & 0 & 0 \\
\hline 41. & 0 & 0 & 0 & 0 & 0 \\
\hline 42. & 0 & 0 & 0 & 0 & 0 \\
\hline 43. & 1 & 0 & 0 & 0 & 0 \\
\hline 44. & 0 & 0 & 0 & 0 & 0 \\
\hline 45. & 0 & 0 & 0 & 0 & 0 \\
\hline 46. & 0 & 0 & 0 & 0 & 0 \\
\hline 47. & 0 & 0 & 0 & 0 & 0 \\
\hline 48. & 0 & 0 & 0 & 0 & 0 \\
\hline 49. & 0 & 0 & 0 & 0 & 0 \\
\hline 50. & 0 & 0 & 1 & 0 & 0 \\
\hline 51. & 0 & 0 & 0 & 0 & 0 \\
\hline 52. & 0 & 0 & 0 & 0 & 0 \\
\hline 53. & 0 & 0 & 0 & 0 & 0 \\
\hline 54. & 1 & 0 & 0 & 0 & 0 \\
\hline 55. & 0 & 0 & 0 & 0 & 0 \\
\hline 56. & 0 & 0 & 0 & 0 & 0 \\
\hline 57. & 0 & 0 & 0 & 0 & 0 \\
\hline 58. & 0 & 0 & 1 & 0 & 0 \\
\hline 59. & 0 & 0 & 0 & 0 & 0 \\
\hline 60. & 0 & 1 & 0 & 0 & 0 \\
\hline 61. & 0 & 0 & 0 & 0 & 0 \\
\hline 62. & 0 & 0 & 0 & 0 & 0 \\
\hline 63. & 0 & 0 & 0 & 0 & 0 \\
\hline 64. & 0 & 0 & 0 & 0 & 0 \\
\hline 65. & 0 & 0 & 0 & 0 & 0 \\
\hline 66. & 1 & 0 & 0 & 0 & 0 \\
\hline 67. & 0 & 0 & 0 & 0 & 0 \\
\hline 68. & 1 & 0 & 0 & 0 & 0 \\
\hline 69. & 0 & 0 & 0 & 0 & 0 \\
\hline 70. & 0 & 0 & 0 & 0 & 0 \\
\hline 71. & 0 & 0 & 0 & 0 & 0 \\
\hline 72. & 0 & 0 & 0 & 0 & 0 \\
\hline 7. & 0 & 0 & 2 & 0 & 0 \\
\hline 74. & 0 & 1 & 0 & 0 & 0 \\
\hline 75. & 0 & 0 & 0 & 0 & 0 \\
\hline 76. & 1 & 0 & 0 & 0 & 0 \\
\hline 78. & 0 & 0 & 0 & 0 & 0 \\
\hline 78. & 0 & 0 & 0 & 0 & 0 \\
\hline 79. & 0 & 0 & 0 & 0 & 0 \\
\hline 80. & 0 & 0 & 0 & 0 & 0 \\
\hline
\end{tabular}




\begin{tabular}{|c|c|c|c|c|c|}
\hline 81. & 0 & 0 & 0 & 0 & 0 \\
\hline 82. & 2 & 0 & 0 & 0 & 0 \\
\hline 83. & 0 & 0 & 0 & 0 & 0 \\
\hline 84. & 0 & 0 & 0 & 0 & 0 \\
\hline 85. & 0 & 0 & 0 & 0 & 0 \\
\hline 86. & 0 & 2 & 0 & 0 & 0 \\
\hline 87. & 0 & 0 & 0 & 0 & 0 \\
\hline 88. & 0 & 0 & 0 & 0 & 0 \\
\hline 89. & 0 & 0 & 0 & 0 & 0 \\
\hline 90. & 0 & 0 & 1 & 0 & 0 \\
\hline 91. & 0 & 0 & 0 & 0 & 0 \\
\hline 92. & 0 & 0 & 0 & 0 & 0 \\
\hline 93. & 0 & 0 & 0 & 0 & 0 \\
\hline 94. & 0 & 0 & 0 & 0 & 0 \\
\hline 95. & 0 & 0 & 0 & 0 & 0 \\
\hline 96. & 0 & 1 & 0 & 0 & 0 \\
\hline 97. & 0 & 0 & 0 & 0 & 0 \\
\hline 98. & 0 & 0 & 0 & 0 & 0 \\
\hline 99. & 0 & 0 & 0 & 0 & 0 \\
\hline 100. & 0 & 0 & 0 & 0 & 0 \\
\hline 101. & 0 & 0 & 2 & 0 & 0 \\
\hline 102. & 0 & 0 & 0 & 0 & 0 \\
\hline 103. & 2 & 0 & 0 & 0 & 0 \\
\hline 104. & 0 & 0 & 0 & 0 & 0 \\
\hline 105. & 0 & 0 & 0 & 0 & 0 \\
\hline 106. & 0 & 0 & 0 & 0 & 0 \\
\hline 107. & 0 & 0 & 0 & 0 & 0 \\
\hline 108. & 0 & 0 & 1 & 0 & 0 \\
\hline 109. & 0 & 0 & 0 & 0 & 0 \\
\hline 110. & 0 & 0 & 0 & 0 & 0 \\
\hline 111. & 0 & 0 & 0 & 0 & 0 \\
\hline 112. & 0 & 1 & 0 & 0 & 0 \\
\hline 113. & 0 & 1 & 0 & 0 & 0 \\
\hline 114. & 0 & 0 & 0 & 0 & 0 \\
\hline 115. & 0 & 0 & 0 & 0 & 0 \\
\hline 116. & 0 & 0 & 0 & 0 & 0 \\
\hline 117. & 0 & 0 & 0 & 0 & 0 \\
\hline 118. & 0 & 0 & 0 & 0 & 0 \\
\hline 119. & 0 & 0 & 0 & 0 & 0 \\
\hline 120. & 0 & 0 & 0 & 0 & 0 \\
\hline TOTAL & 11 & 9 & 10 & 0 & 10 \\
\hline
\end{tabular}




\section{Referências Bibliográficas*}

1. ADAMO, H.L. et al. A comparison of MTA, Super-EBA, composite and amalgam as root-end filling materials using a bacterial microleakage model. Int Endod J v.32, n.3, p.197-203, May 1999.

2. AQRABAWI, J. Sealing ability of amalgam, Super-EBA cement, and MTA when used as retrograde filling materials Br Dent J, v.188, n.5, p.266-268, Nov 2000.

3. AL-GHAMDI, A.; WENNBERG, A. Testing of sealing ability of endodontic filling materials. End Dental Traumatol, v.10, n.6, p.249-255, Dec 1994.

4. AL-NAZHAN, S.; AL-JUDAI, A. Evaluation of antifungal activity of mineral trioxide aggregate. J Endod, v.29, n.12, p.826-827, Dec 2003.

5. ANDELIN, W.E. et al. Microleakage of resected MTA. J Endod, v.28, n.8, p.573-574, Aug 2002.

6. ANTÔNIO, M.P.S.; MOURA, A.A.M. Análise "in vitro" do selamento marginal apical de obturações realizadas com cones de guta-percha associados a 4 tipos de cimento. Rev Odontol Univ São Paulo, v.11, n.1, p.6166, Jan/Mar 1997.

\footnotetext{
Normas recomendadas para o uso no âmbito da Universidade de São Paulo com base no documento "Referências Bibliográficas: exemplos”, emanado do Conselho Supervisor do Sistema Integrado de Bibliotecas da USP em reunião de 20 de setembro de 1990.
} 
7. ARAÚJO, R.A. et al. Avaliação do selamento apical após retrobturações com a utilização de duas diferentes marcas de MTA. J Bras Endod, v.5, n. 17, p.150-156, Abr/Jun 2004.

8. ASGARY, S. et al. Chemical differences between white and gray mineral trioxide aggregate. J Endod, v.31, n.2, p.101-103, Feb 2005.

9. BARKHORDAR, R.A. Evaluation of antimicrobial activity in vitro of ten root canal sealers on Streptococcus sanguis and Streptococcus mutans. Oral Surg Oral Med Oral Pathol, v.68, n.6, p.770-772, Dec 1989.

10.BARTHEL, C.R. et al. Bacterial leakage versus dye leakage in obturated root canals. Int Endod J, v.32, n.5, p.370-5, Sep 1999.

11.BATES, C.F.; DAVID, L.C.; del RIO, C. Longitudinal sealing ability of mineral trioxide aggregate as a rootend filling material. J Endod, v.22, n.11, p.575-578, Nov 1996.

12.BERNABÉ, P.F.E. et al. Avaliação da capacidade seladora de alguns materiais retrobturadores. ROBRAC, v.11, n.32, p.68-71, 2002.

13.BERNABÉ, P.F.E.; HOLLAND, R. Cirurgia parendodôntica: como praticá-la com embasamento cientifico. In: Carlos Estrela. Ciência endodôntica. São Paulo. Artes Médica, 2004. Cap.16, p.657-797. 
14.BRAMANTE, C. M.; BERBERT, A. Cirurgia Parendodôntica. São Paulo, Ed. Santos, 2000.

15.BRONG, C.W. et al. Sealing ability of four endodontic sealers. Br Dent J, v.201, n.4, p.17-19, April 2002.

16.CAMPS, J.; PASHLEY, D. Reliability of the dye penetration studies. J Endod, v.29, n.9, p.592-94, Sep 2003.

17. CANALDA, C.; PUMAROLA, J. Bacterial growth inhibition produced by root canal sealer cements with a calcium hydroxide base. Oral Surg Oral Med Oral Pathol, v.68, n.1, p.99-102, July 1989.

18. CANALDA-SAHLI, C. et al. The apical seal of root canal sealing cements using a radionuclide detection technique. Int Endod J, v.25, n.5, p.250-256, Sep 1992.

19. CHAPMAN, D.R.F. et al. Leakage evaluation of three root end filling materials. J Endod, v.16, n.3, p.182-185, Mar 1990.

20. ÇOBANKARA, F.K. et al. In vitro antibacterial activities of root-canal sealers by using two different methods. J Endod, v.30, n.1, p.57-60, Jan 2004.

21.DALÇÓQUIO, C. et al. Selamento apical após obturação com MTA, IRM, ionômero de vidro e cianoacrilato. Rev APCD, v.55, n.3, p.194-198, Mai-Jun 2001. 
22. DELIVANIS, P.; TABIBI, A. A comparative sealability of different retrofilling materials. Oral Surg Oral Med Oral Pathol, v.45, n.2, p.273-81, Feb 1978.

23.DUARTE, M.A.H.; WECKWERTH, P.H.; MORAES, I.G. Análise da ação antimicrobiana de cimentos e pastas empregadas na prática endodôntica. Rev Odontol Univ São Paulo, v.11, n.4, p.299-305, Out-Dez 1997.

24.DUARTE, M.A.H et al. Evaluation of $\mathrm{pH}$ and Calcium ion release of three root canal sealers. J Endod, v.26, n.7, p.389-90, July 2000.

25.DUARTE, M.A.H et al. Avaliação da contaminação do MTA Angelus e do cimento Portland. JBC, v.6, n. 32, p.155157, Mar/Abr 2002.

26. ESTRELA, C et al. Análise da ação antimicrobiana de três cimentos obturadores contendo hidróxido de cálcio. Rev ABO Nacional, v.3, n.3, p.185-187, jun-jul 1995.

27. ESTRELA, C et al. Antimicrobial and chemical study of mineral trioxide aggregate, Portland cement, calcium hydroxide paste, Sealapex and Dycal. Braz Dental J, v.11, n.1, p.3-9, 2000.

28.FARACO JÚNIOR, I.M. Avaliação histomorfológica da resposta da polpa de dentes de cães submetida ao capeamento com sistema adesivo, cemento de hidróxido de cálcio e dois tipos de agregado de trióxido mineral. Araçatuba, 1999. 251p. Tese 
(Doutorado) - Faculdade de Odontologia de Araçatuba, Universidade Estadual Paulista.

29.FARACO JÚNIOR, I.M.; HOLLAND, R. Response of the pulp of dogs to capping with Mineral Trioxide Aggregate or a Calcium Hydroxide cement. Dental Traumatol, v.17, n.4, p.163-66, Aug 2001.

30.FISCHER, E.J.; AREN, D. E.; MILLER, C. H. Bacterial leakage of mineral trioxide aggregate as compared with zinc-free amalgam, intermediate restorative material, and Super-EBA as root-end filling material. J Endod, v.24, n.3, p.176-9, Mar 1998.

31.FUSS, Z.; WEISS, E.; SHALHAV, M. Antimicrobial activity of calcium hydroxide. Containing endodontic sealers on Enterococcus faecalis "in vitro". Int Endod J, v.30, n.6, p.397-402, Nov 1997.

32.FUNTEAS, U.R.; WALLACE, J.A.; FOCHTMAN, E.W. A comparative analysis of mineral trioxide aggregate and Portland cement. Aust. Endod. J., v.29, n.1, p.43-4, Apr 2003.

33.GILHEANY, P.A.; FIGDOR, D.; TYAS, M.J. Apical dentin permeability and microleakage associated with root end resection and retrograde filing. J Endod, v.20, n.1, p.22-26, Jan 1994. 
34.GOMES, B.P.F.A. Microrganismos: quais São, Omde estão, que Danos causam? Endodontia/Trauma. São Paulo. Artes Médica, 2002. Cap.5, p.77-98.

35.GONÇALVES, S.B. Avaliação "in vitro" da capacidade seladora do Super-EBA e do MTA em quatro técnicas de obturação retrógrada. Bauru, 2002. 129 p. Dissertação (Mestrado) - Faculdade de Odontologia de Bauru, Universidade de São Paulo.

36.GUTMANN, J.; FAVA, L. R. G. Perspectives on periradicular healing using sealapex: a case report. Int Endod J, v.24, n.3, p.135-138, May 1991.

37.HAÏKEL. Y. et al. A new method for the quantitative analysis of endodôntico microleakage. J Endod, v.25, n.3, p.172-177, Mar. 1999.

38. HARTY, F.J.; PARKINS B.J.; WENGRAF, A.M. The success rate of apicectomy. A retrospective study of 1016 cases. Br Dent J , v.13, n.3, p.407-413, Nov. 1970 .

39.HELING, I.; CHANDLER, N.P. The antimicrobial effect within dentinal tubules of four root canal sealers. J Endod, v.22, n.5, p.257-9, May 1996.

40.HOLLAND, R.; SOUZA, V. Ability of a new calcium hydroxide root canal filling material to induce hard tissue formation. J Endod, v.11, n.12, p.535-43, Dec 1985. 
41. HOLLAND, R. et al. Infiltração marginal dos cimentos endodônticos. RGO, v.39, n.6, p.413-16, Nov-Dez 1991.

42. HOLLAND, R. et al. Análise do selamento marginal obtido com cimentos à base de hidróxido de cálcio. APCD, v.50, n.1, p.61-64, Jan-Fev 1996.

43. HOLLAND, R. et al. Mineral Trioxide Aggregate repair of lateral root perforations. J Endod, v.27, n.4, p.281-84, Apr 2001.

44.KAKEHASHI, S.; STANLEY H.R.; FITTZGERALD R.J.; The effects of surgical exposure of dental pulps in germ free and conventional laboratory rats. Oral Surg Oral Med Oral Pathol v.20; p.340-9; Sep 1965.

45.KERSTEN, H.W.; MOORER, W.R. Particles and molecules in endodontic leakage. Int Endod J, v.22, n.3, p.118124, May 1989.

46. KIM, S. et al. Microsurgery in endodontics. W.B Saunders Company, 2001, 172p

47.KRAKOW, A.A.; DE STOPPELAAR, J.D.; GRON, P. In vivo study of temporary filling materials used in endodontics in anterior teeth. Oral Surg Oral Med Oral Pathol v.43; p.615-620; Apr 1977.

48.LEE, S.J.; MONSEF, M.; TORABINEJAD, M. Sealing ability of a Mineral Trioxide Aggregate for repair of lateral root perforations. J Endod, v.19, n. 11, p.541-44, Nov 1993. 
49. LEIMBURG et al. MTA obturation of pulpless teeth with open apices: Bacterial leakage $s$ detected by polymerase chain reaction assay. J Endod, v.30, n. 12, p.883-886, Dec. 2004.

50.LEONARDO, M.R. et al. Hidróxido de cálcio em endodontia: avaliação da alteração do $\mathrm{pH}$ e da liberação de íons cálcio em produtos endodônticos a base de hidróxido de cálcio. RGO, v.40, n.1, p.69-72, jan-fev 1992.

51. LEONARDO, R.T. Avaliação microscópica da reação apical e periapical frente a dois cimentos obturadores de canais radiculares à base de hidróxido de cálcio (CRCS e Sealapex) em dentes de cães. Bauru, 1992. 108p. Dissertação (Mestrado) Faculdade de Odontologia de Bauru, Universidade de São Paulo.

52. LUIZ, M.R. Avaliação do reparo apical e periapical, em dentes de cães com lesão periapical após obturação retrógrada com diferentes materiais retrobturadores. Araraquara, 2003. 193p. Tese (Doutorado) - Faculdade de Odontologia de Araraquara, Universidade Estadual Paulista.

53. MAGURA, M.E. et al. Human saliva coronal microleakage in obturated root canals: "in vitro" study. J Endod, v.17, n. 7, p.324-331, July. 1991. 
54.MANGIN, C. et al. The comparative sealing ability of hydroxyapatite cement, Mineral Trioxide Aggregate, and Super-EBA as root-end filling materials. J Endod, v.29, n. 4, p.261-264, Apr. 2003.

55.MATLOFF, I.R. et al. A comparasion of methods used in root canal sealability studies. Oral Surg Oral Med Oral Pathol, v.53, n.2, p.203-8, Feb 1982.

56. MENEZES, R. Histologic evaluation of pulpotomies in dog using two types of mineral trioxide aggregate and regular and White Portland cements as wound dressing. Oral Surg Oral Med Oral Pathol, v.98, n.3, p.376-379, Sep 2004.

57.MICKEL, A.K.; NGUYEN, T.H.; CHOGLE, S. Antimicrobial activity of endodontic sealers on Enterococcus faecalis. J Endod, v.29, n.4, p.257-58, Apr 2003.

58.MILLER, W.D. An introduction to the study of the bacteriopathology of the dental pulp. Dent Cosmos v.36, p.505-528, Dec 1894.

59.MÖLLER, A.J.R. Influence of periapical tissues of indigenous oral bactéria and necrotic pulp tissue in monkeys. Scand J Dent Res, v.89, n.6, p.475-84, Dec 1981.

60.MORANDI, R. Avaliação histomofológica realizada em dentes de cães com lesão periapical, após apicectomia e obturação retrógrada convencional com cimentos a base de óxido de zinco e eugenol e 
o agregado de trióxido mineral. Araçatuba, 1999. 319p. Dissertação (mestrado) - Faculdade de Odontologia de Araçatuba, Universidade Estadual Paulista.

61.MORTENSEN, D.W.; BOUCHER, N.E.; RYGE, G. A method of testing for marginal leakage of dental restorations with bacteria. J. Dent Res, v.44, p.58-63, Jan-Feb 1965.

62.PARIROKH, M. et al. A comparative study of white and grey mineral trioxide aggregate as pulp capping agents ind dog's teeth. Dental Traumatol, v.21, n.3, p.150-54 Jun 2005.

63.PINHEIRO, E.T. Investigação de bactérias associadas ao insucesso do tratamento endodôntico. Piracicaba, 2000. 185p. Dissertação (mestrado) - Faculdade de Odontologia de Piracicaba, Universidade Estadual de Campinas.

64.POMMEL, L. et al. Apical leakage of four endodontic sealers. J Endod, v.29, n.3, p.208-210, Mar 2003.

65.REGALADO, D.F. et al. Análise da variação de pH entre cimentos MTA e Portland em diferentes períodos de tempo. Brazilian Oral Research, v.17, p.229, Setembro 2002. Suplemento.

66.ROCHA, W.C. Avaliação dos efeitos da infiltração microbiana, por via coronária, em dentes de cães submetidos a obturação retrógrada com MTA. 
Araçatuba, 2003. 233p. Tese (Doutorado) - Faculdade de Odontologia de Araçatuba, Universidade Estadual Paulista.

67.SCHÄFER, E.; ZANDBIGLARI, T. Solubility of root-canal sealers in water and artificial saliva. Int Endod J, v.36, n.10, p.660-668, Oct 2003.

68.SCHEERER, S.Q.; STEIMAN, H.R.; COHEN, J. Acomparative evaluation of three root-end filling materials: An in vitro leakage study using Prevotella nigrescens. J Endod, v.27, n.1, p.40-42, Jan. 2001.

69. SILVA, L.A.B. Cimentos obturadores de canal radicular à base de hidróxido de cálcio. Avaliação histopatológica de reparo apical e periapical em entes de cães, da resposta inflamatória em tecido subcutâneo e da migração celular em cavidade peritoneal de camundongos. Ánálise do $\mathrm{pH}$, concentração de cálcio total e condutividade. Ribeirão Preto, 1995. 191p. Tese (Livre-Docência) - Faculdade de Odontologia de Ribeirão Preto, Universidade de São Paulo.

70.SILVA NETO, U.X. et al. Infiltração marginal em obturações retrogrades realizadas com Pro Root - MTA, MTA - Angelus e Super-EBA. JBE., v.4, n.13, p.149152, Março/Abril. 2003.

71.SILVA E SOUZA, P.A.R. Estudo "in vitro" da infiltração bacteriana em obturações radiculares em dentes bovines (influência do uso do E.D.T.A. à $17 \%$ e do laser de Er:YAG e Nd:YAG). Bauru, 2004. 116p. Tese 
(Doutorado) - Faculdade de Odontologia de Bauru, Universidade de São Paulo.

72.SIQUEIRA, D.C.R. et al. Avaliação da infiltração bacteriana de cimentos utilizados na retrobturação. Brazilian Oral Research, v.18, p.162, Setembro 2004. Suplemento.

73.SIQUEIRA JR., J.F; GARCIA FILHO, P.F. Avaliação "in vitro" das propriedades seladoras de três cimentos endodônticos à base d hidróxido de calcio. R B $\mathbf{O}$., v.51, n.1, p.37-40, Jan-Fev. 1994.

74.SIQUEIRA JUNIOR., J.F.; GONÇALVES, A.B. Antibacterial activities of root canal sealers against selected anaerobic bacteria. J Endod, v.22, n.2, p.79-80, Feb. 1996.

75.SWITZER, S.; MOSHONOV, J.; TROPE, M. In vitro comparasion of bacterial and dye leakage of obturated canals. J Endod., v.18, n.3, p.194, May 1992. Abstract.

76. TAGGER, M,; TAGGER, E. Periapical reactions to calcium hydroxide containg sealers and $\mathrm{AH} 20$ in monkeys. End Dental Traumatol, v.5, n.3, p.139-146, June, 1989.

77.TAGGER, M.; TAGGER, E.; KFIR. A. Release of calcium and hydroxyl ions from set endodontic sealers containg calcium hydroxide. J Endod, v.14, n.12, p.588-91, Dec 1988. 
78.TANG, H.M.; TORABINEJAD, M.; KETTERING, J.D. Leakage evaluation of root end filling materials using endotoxin. J Endod, v.28, n.1, p.5-7, Jan 2002.

79. TANOMARU FILHO, M., et al. Effect of different root canal sealers on periapical repair of teeth with chronic periradicular periodontitis. Int Endod J v.31, n.2, p.8589, Mar 1998.

80.TORABINEJAD, M.; UNG, B.; KETTERING, J.D. In vitro bacterial penetration of coronally unsealed endodontically treated teeth. J Endod, v.16, n.12, p.566-569, Dec 1990.

81.TORABINEJAD, M.; WATSON, T.F.; PITT FORD, T.R. Sealing ability of a Mineral Trioxide aggregate when used as a root end filling material. J Endodon, v.19, n.12, p.591-95, Dec 1993.

82.TORABINEJAD, $M$. et al. Dye leakage of four root end filing materials: Effects of blood contamination. J Endod, v.20, n.4, p.159-163, Apr 1994. (F)

83.TORABINEJAD, $M$. et al. Bacterial leakage of Mineral Trioxide Aggregate as a root-end filing material. J Endod, v.21, n.3, p.109-112, Mar 1995.

84.TORABINEJAD, $M$. et al. Comparative investigation of marginal adaptation of Mineral Trioxide Aggregate and other commoly used root-end filing materials. J Endod, v.21, n.6, p.295-299, Jun 1995. 
85.TORABINEJAD, M. et al. Physical and chemical properties of a new root-end filling material. J Endod, v.21, n.7, p.349-353, July 1995.

86.TORABINEJAD, M. et al. Antibacterial effects of some root-end filing materials. J Endod, v.21, n.8, p.403-406, Aug 1995.

87.TORABINEJAD, M. et al. Investigation of Mineral Trioxide Aggregate for root-end filing in dogs. J Endod, v.21, n.12, p.603-608, Dec 1995.

88.TORABINEJAD, M.; CHIVIAN,N. Clinical applications of a Mineral Trioxide Aggregate. J Endod, v.25, n.3, p.197205, Mar. 1999.

89.TRONSTAD, L.; BARNET, F.; FLAX, M. Solubility and biocompatibility of calcium hydroxide-containing root canal sealers. End Dental Traumatol, v.4, n.4, p.152159, Aug 1988.

90.TSELNIK, M.; BAUMGARTMER, J.C.; MARSHALL, G. Bacterial leakage with mineral trioxide aggregate or a resin-modified glass ionomer ued as a coronal barrier. J Endod, v.30, n.11, p.782-784, Nov 2004.

91. VALERA, M.C. Estudo da compatibilidade biológica de alguns cimentos à base de hidróxido de cálcio e um cimento de ionômero de vidro: avaliação do selamento marginal apical e análise morfológica por microscopia de força atômica. Araraquara, 1995. 
333p. Tese (Doutorado) - Faculdade de Odontologia de Araraquara, Universidade Estadual Paulista.

92. WADA et al. Clinical study of refractory apical periodontitis treated by apicoectomy. Part I. Root canal morphplogy of resected apex. Int Endod J. v.31, n.1, p.53-56, Jan 1998.

93.WU, M.K; WESSELINK, P.R. Endodontic leakage studies reconsidered. Part 1. Methodology, application and relevance. Int Endod J. v.43, n.1, p.37-43, Jan 1993.

94.WU, M.K; DE GEE, A.J.; WESSELINK, P.R. Fluid transport and dye penetration along root canal fillings. . Int Endod J. v.27, n.5, p.233-238, Sep 1994. 


\section{ABSTRACT}

\section{A comparative study of sealing ability of white and gray MTA Angelus and Sealapex added of zinc oxide as root-end filling materials using a bacterial microleakage model.}

The cements gray MTA Angelus, white MTA Angelus and Sealapex added of zinc oxide (consistent Sealapex) were evaluated accordind to their sealer abilility to the bacterial leakage. Eighty single-rooted extracted human teeth were used, all of them had their crown removed. The roots were divided aleatory in three experimental groups of 20 specimen, one for each cement, and in two groups of controls of 10 specimen each. The roots were resectioned with a 90 angle in relation to the long opening and were made 3 millimeters retrocavities deep, the external surface of all of the roots was impermeabled with Araldite, except the resectioned one. The roots were put in tubes of microcentrifuge and fixed with Araldite. The set (radix dentis and the tube of microcentrifuge) was sterilized in ethylene oxide, before this sterilization the retrocavities were filled with the tested cements, and this set was assembled in vials such as penicillin, containing $\mathrm{BHI}$ broth sterile. After this procedure, we deposited $400 \mu \mathrm{l}$ of Enterococcus faecalis culture ATCC 29212 inside the tube of microcentrifuge. The display (root, tube of microcentrifuge, glass and bacterium) was kept in kiln $37^{\circ} \mathrm{C}$, during 120 days to the examination of blurriness of the culture, indicated of bacterium leakage, being the culture media inside the tube of microcentrifuge renovating weekly.

At this time appeared leakage in 11 specimen of the gray MTA

group, in 10 of consistent Sealapex and 9 of white MTA. Applying the Chi-Square Test to the achieved results, it was concluded 
that the tested cements behaved similar to the bacterium leakage during the tested experimental period. 